\title{
10. METAMORPHOSED SEDIMENTARY (VOLCANICLASTIC?) ROCKS BENEATH PALEOCENE BASALT IN HOLE 917A, EAST GREENLAND MARGIN ${ }^{1}$
}

\author{
Tracy Vallier, ${ }^{2}$ Lewis Calk, ${ }^{3}$ Rainer Stax,${ }^{4}$ and Alain Demant ${ }^{5}$
}

\begin{abstract}
Ocean Drilling Program Leg 152 drilled Hole 917A first through Quaternary and Eocene sediments, then through about 779 $\mathrm{m}$ of Paleocene basalt and interlayered dacite that comprise the dipping seismic reflectors along the southeast Greenland margin, and thence into about $53.7 \mathrm{~m}$ of steeply dipping and metamorphosed sandstone and siltstone. Ten centimeters of quartz sandstone, probably of fluvial origin, was recovered between the basalt and metamorphosed sedimentary rocks. The sedimentary rocks, believed to be in part volcaniclastic, are mostly well-bedded turbidites and laminites and, in places, are intensely burrowed. Minerals are characteristic of the greenschist facies and consist of albite, chlorite, quartz, graphite, white mica, and epidote with lesser amounts of biotite, sphene/leucoxene, and pyrite. Normalized $\mathrm{SiO}_{2}$ contents range from about 50 to 60.6 wt $\%$ and average about $54.4 \mathrm{wt} \%$. $\mathrm{Na}_{2} \mathrm{O}$ is highly variable with albite-rich specimens having as much as $7.6 \mathrm{wt} \%$ and albitepoor specimens as little as $1.5 \mathrm{wt} \% . \mathrm{K}_{2} \mathrm{O}$ contents range from a low of $0.04 \mathrm{wt} \%$ to a high of $2.32 \mathrm{wt} \%$; variation is related to white mica content. Organic carbon contents range from about $0.3 \mathrm{wt} \%$ to $3.28 \mathrm{wt} \%$, with an average of about $1.0 \mathrm{wt} \%$. Mineralogy and chemistry suggest a volcanic (basaltic) source. Temperature of metamorphism was greater than $350^{\circ} \mathrm{C}$, and possibly as high as $450^{\circ} \mathrm{C}$, as shown by the crystallinity of graphite, chlorite geothermometry, and the presence of metamorphic biotite. The characteristics of similar onshore rocks from East Greenland, within the Late Cretaceous (Maastrichtian)-early Paleocene Ryberg Formation, may suggest a correlation with the metamorphosed sedimentary rocks recovered near the base of Hole 917A. We presume that the sediments were deposited in a basin during early rifting of the continents that led to the formation of the North Atlantic Ocean basin, possibly during the Late Cretaceous-earliest Paleocene interval. The original sediments were tilted, raised above sea level and eroded, and then buried beneath a thick section of basalt and dacite. Metamorphism at high temperatures and low pressure ( $2-4 \mathrm{~kg}$ ?) probably took place prior to burial by the volcanic cover. The entire sequence was faulted and tilted during subsequent opening and spreading apart of the North Atlantic Ocean basin.
\end{abstract}

\section{INTRODUCTION}

Metamorphosed sedimentary rocks were unexpectedly recovered beneath a thick pile of Paleocene basalt and dacite in Hole 917A (Figs. 1, 2). Outcrops of crystalline Precambrian rocks along the east coast of Greenland, about $50 \mathrm{~km}$ west of Site 917, led us to believe that similar crystalline rocks would be encountered beneath the Tertiary volcanic rocks. However, pre-basaltic sediments, in part as thin layers, are fairly widespread farther north along the margin (see Larsen, 1980, for review). Thus, the occurrence of the metamorphosed sedimentary rocks has important implications for the early opening of the North Atlantic Ocean basin, and for the tectonic and hydrothermal regimes that led to metamorphism.

This paper (1) describes the structure, stratigraphy, sedimentology, mineralogy, and chemistry of the rocks; (2) interprets the source rocks and environment of deposition of the sediments; (3) speculates about temperatures, pressures, and ion mobilities during metamorphism; and (4) briefly discusses the implications of these rocks for North Atlantic Ocean basin history.

We studied thin sections of 25 samples; obtained X-ray diffraction (XRD) patterns of 13 specimens; conducted carbon and carbonate analyses of 13 samples; submitted 16 samples (two on board) for

${ }^{1}$ Saunders, A.D., Larsen, H.C., and Wise, S.W., Jr. (Eds.), 1998. Proc. ODP, Sci. Results, 152: College Station, TX (Ocean Drilling Program).

${ }^{2}$ U.S. Geological Survey, MS-919, 345 Middlefield Road, Menlo Park, CA 94025, U.S.A.tvallier@usgs.gov U.S.A

${ }^{3}$ U.S. Geological Survey, MS-910, 345 Middlefield Road, Menlo Park, CA 94025,

${ }^{4}$ Institute for Geology and Mineralogy, University of Erlangen, Schlossgarten 5, 91054 Erlangen, Federal Republic of Germany.

${ }^{5}$ Laboratoire de Pétrologie Magmatique, Université d'Aix-Marseille III, 13397 Marseille Cedex 20, France. major, minor, and trace element chemistry; and completed microprobe analyses on chlorite and albite in selected polished thin sections. We attempted to separate muscovite grains for K-Ar radiometric dating, but the very fine grain size precluded a clean separation by the techniques we used. Details of methods used in the analyses are described in the sections that present the data.

\section{STRUCTURE, STRATIGRAPHY, AND SEDIMENTOLOGY}

A total of $874.9 \mathrm{~m}$ was cored in Hole 917A (Shipboard Scientific Party, 1994) which included, from top to bottom: (1) Quaternary glaciomarine sediments; (2) middle Eocene siltstone; (3) a small interval (about $4 \mathrm{~m}$ ) of weathered basalt interlayered with conglomerate, breccia, and paleosols; (4) a thick (about $775 \mathrm{~m}$ ) sequence of Paleocene basalt and dacite in three units or series (for age of these, see Sinton and Duncan, this volume); (5) a very thin (about $10 \mathrm{~cm}$ ) layer of quartz sandstone; and (6) a sequence of metamorphosed sedimentary (volcaniclastic?) rocks that were encountered at a depth of about 821 meters below seafloor (mbsf). Approximately $15.9 \mathrm{~m}$ of these sedimentary rocks was recovered within the $53.7 \mathrm{~m}$ cored (Cores $152-917 \mathrm{~A}-103 \mathrm{R}$ through $110 \mathrm{R}$ ) for a recovery rate of about $30 \%$. These metamorphosed volcaniclastic(?) sedimentary rocks in the bottom unit of Hole 917A are the subject of this paper.

The metamorphosed sedimentary rocks, originally sand, silt, clay, and possibly tuffs, were lithified and then deformed. Bedding dips within the sequence range from about $30^{\circ}-35^{\circ}$ to overturned, and all beds dip more steeply (Fig. 3) than the overlying lava flows. Bedding dips increase downcore from about $30^{\circ}$ near the top of Core 152917A-103R to vertical (and overturned) in Core 104R, and then to a steep dip of about $70^{\circ}-80^{\circ}$ in Cores $105 \mathrm{R}-110 \mathrm{R}$ (Larsen, Saunders, Clift, et al., 1994). The presence of microfaults indicates that the sed- 
Figure 1. Map of the North Atlantic Ocean showing the sites drilled during Leg 152 and sites drilled previously during DSDP and ODP legs and the location of the main seaward-dipping reflector sequences (SDRS), major early Tertiary basalt outcrop and subcrop, and the broad division into Caledonian and pre-Caledonian crustal blocks (in Greenland and Scandinavia). Abbreviations, from north to south: KR = Knipovich Ridge; GFZ = Greenland Fracture Zone; SFZ = Senja Fracture Zone; JMFZ = Jan Mayen Fracture Zone; JMR = Jan Mayen Ridge; GIR = Greenland-Iceland Ridge; FIR = Faeroes-Iceland Ridge. Selected seafloor-spreading magnetic anomalies are shown (figure from Larsen, Saunders, Clift, et al., 1994).
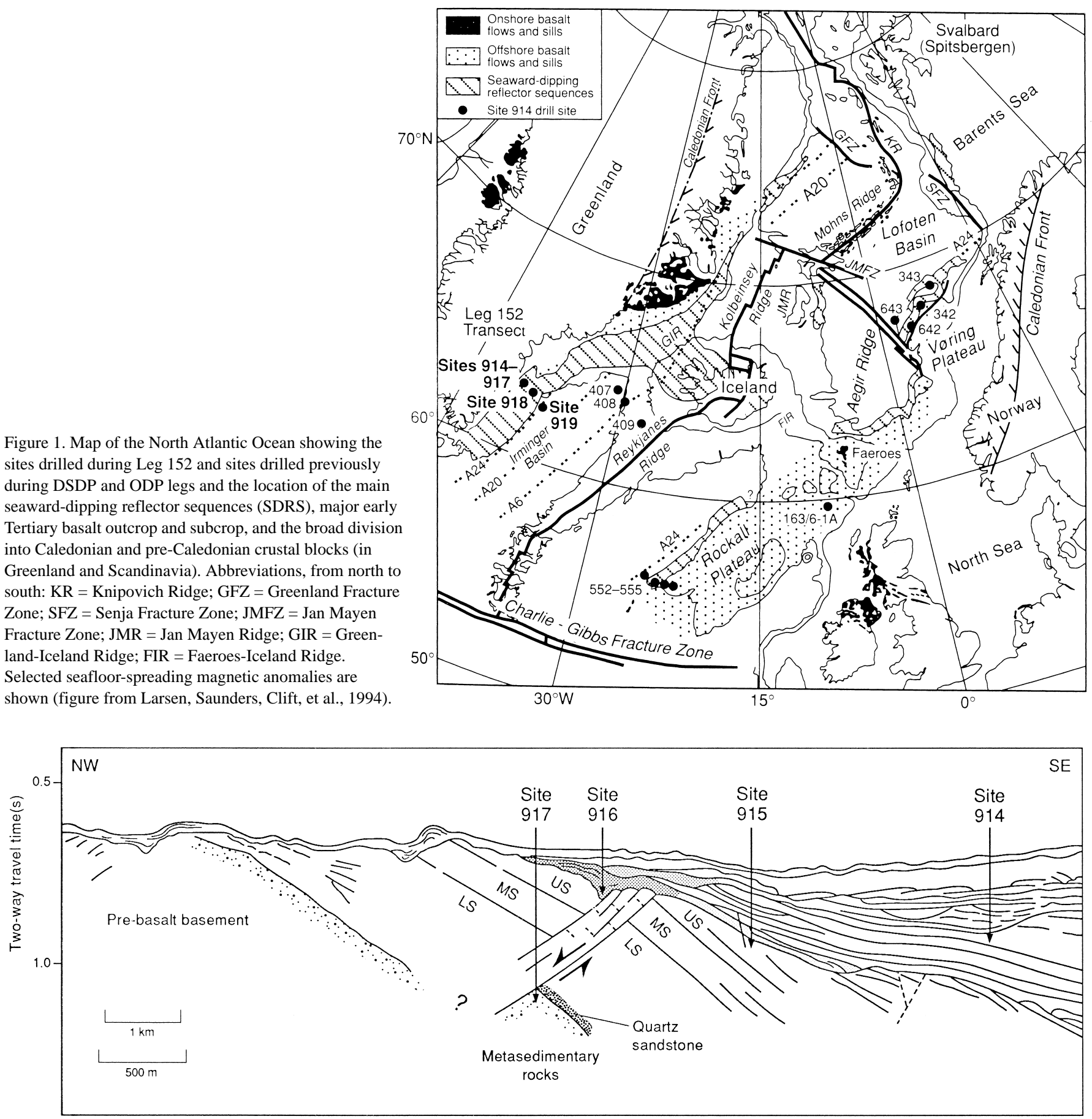

Figure 2. Sites drilled during ODP Leg 152 on the shelf of the East Greenland Margin. The coast of Greenland is about $50 \mathrm{~km}$ west of Site 917 . Reconstruction of the position of the three lava series (LS, MS, and US) established in Hole 917A within the innermost part of the SDRS is based on seismic profile GGU9224. Dips of lavas are exaggerated. The volcanic metasediments described in this chapter occur at the base of Hole 917A (figure is slightly modified from Larsen, Saunders, Clift, et al., 1994).

iments were lithified before tilting; however, no fracture cleavage is evident and Chondrites(?) burrows are essentially undeformed.

The rocks are somewhat finer grained and more carbon-rich near the top of the cored sequence, with less carbon and somewhat coarser grained beds occurring downsection. The concentration of carbon near the top may be a consequence of post-depositional migration. Colors are mostly gray and black with several partially oxidized intervals of olive yellow. Some bedding characteristics suggest deposi- tion from turbidity currents. In general, the beds consist of fine and coarse laminae, 1-10 $\mathrm{mm}$ thick. Graded (from sand to silt) beds, as thick as $2 \mathrm{~cm}$, and rare low-amplitude ripples and cut-and-fill features occur in some parts of the sequence. Chondrites(?) burrows, now filled with secondary minerals, are common; burrows comprise nearly $50 \%$ of some thin sections.

Recrystallization and replacement during metamorphism destroyed the original minerals and some sedimentary features. Thin 


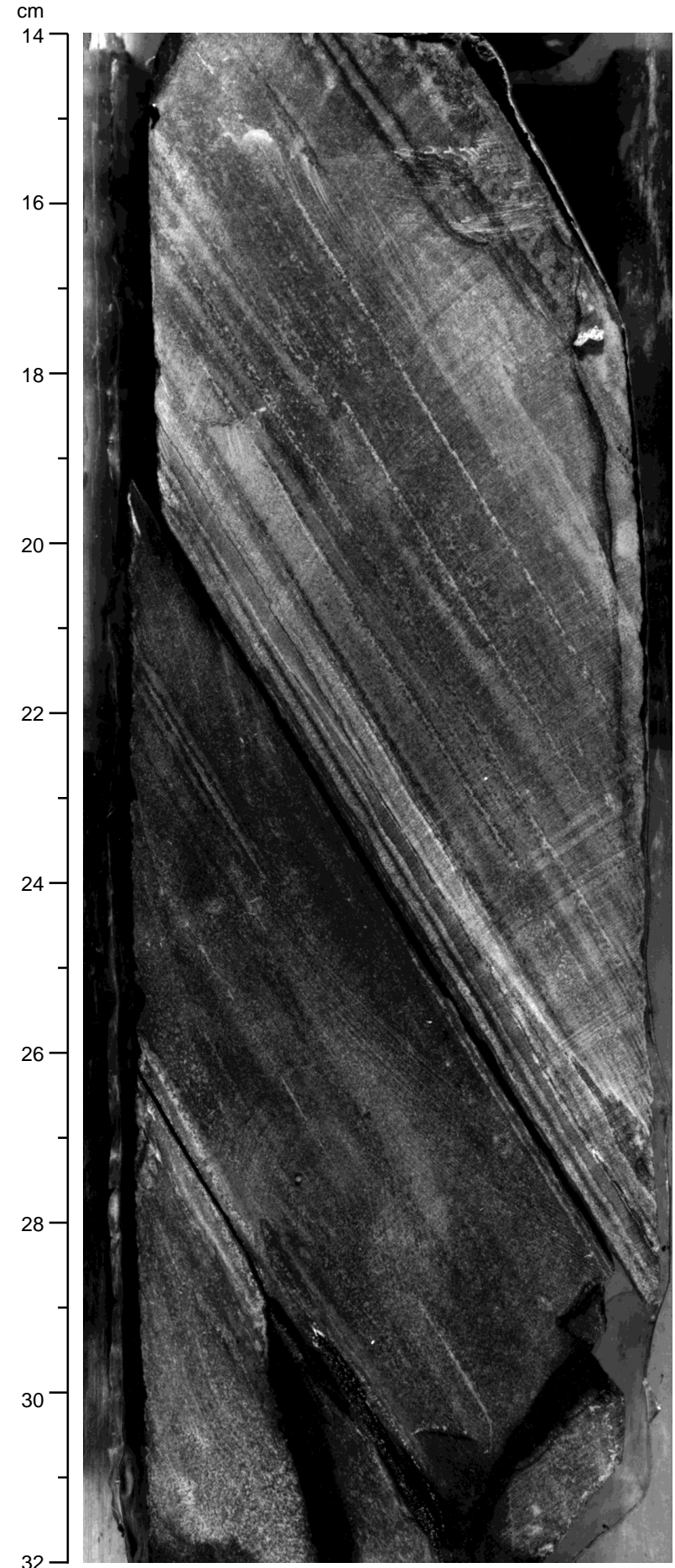

Figure 3. Sample 152-917A-103R-3, 14-32 cm, showing bedding characteristics and dip of laminae.

section studies of several coarse-grained beds show that originally they were composed almost entirely of plagioclase feldspar grains, now replaced by albite and/or chlorite (Fig. 4). Other coarse-grained beds consist of irregular rock fragments that are replaced by albite, chlorite, and quartz. These beds may have been lithic tuffs, consisting originally of plagioclase, volcanic glass(?), and volcanic rock fragments. Furthermore, ovoid (flattened parallel to bedding) quartz/albite masses in some thin sections may be replaced by vesicular vol-

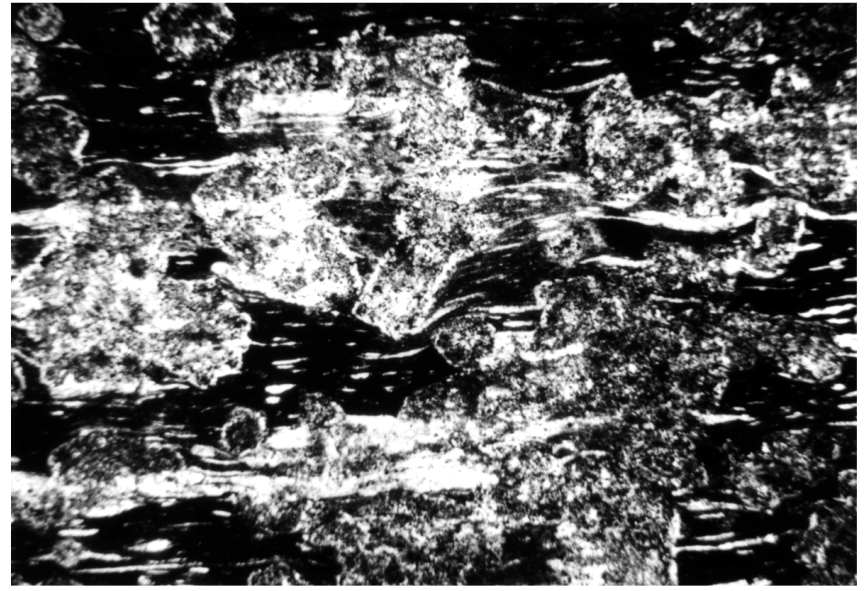

Figure 4. Feldspar grains and probable rock fragments entirely replaced by the secondary minerals chlorite, albite, epidote, and quartz. Sample 152917A-103R-2, 16-20 cm. Fine-grained matrix may originally have been glass and carbon. Field of view is $4.2 \mathrm{~mm}$; plane-polarized light.

canic glass. The rare occurrence of replaced or recrystallized spherical structures (about $1 \mathrm{~mm}$ in diameter), composed of albite and quartz, suggests the original presence of radiolarians; a few irregular and nonspherical, but somewhat bulbous, structures may be replaced foraminifers.

The fine-grained textures of the sediments, combined with the presence of turbidite beds, suggest that the sediments were either deposited in a deep basin or a long distance from the source terrane(s). Alternatively, the source terrane(s) may have had low relief and been relatively close to the depositional basin. The possible occurrence of radiolarians and foraminifers suggests that the basin was marine. The preservation of carbon implies that the basin had either sluggish deep-water circulation or high sedimentation rates. The bottom waters had sufficient oxygen to sustain Chondrites(?), but evidence for other benthic and intrastratal communities is rare, thereby suggesting reducing seafloor conditions. Sediments were transported mostly by turbidity currents. Volcanic ash may have contributed significantly to the sediment volume, based on thin section studies of coarser-grained beds, but extensive burrowing and subsequent replacement of primary minerals and rock fragments during metamorphism have destroyed conclusive evidence.

\section{QUARTZ SANDSTONE}

The thin (about $10 \mathrm{~cm}$ ) bed of brown quartz sandstone (Fig. 5) that lies between the metamorphosed sedimentary rocks and Paleocene basalt flows is important for interpretations of age and geologic history. The small amount of material precludes an accurate dip measurement. However, the sandstone bed seems to have a dip similar to the overlying basalt sequence and less than the dip of the underlying metasedimentary rocks.

The quartz sandstone is texturally immature, having moderately sorted, subangular to well-rounded grains, but it is mineralogically mature consisting mostly of quartz grains and rare grains of quartzite, feldspar, mica, and chert. The quartzite grains are well rounded; the quartz and most other grains are subangular and subrounded. Contacts between grains are sharp and unsutured, indicating that minimal recrystallization occurred. We suspect that the sandstone is fluvial in origin, but the small amount available for study precludes a convincing interpretation. Most likely, a deeply weathered source terrane provided the mature mineral assemblage and a relatively short distance of fluvial(?) transport led to the relatively immature texture. 
The underlying sedimentary rocks are metamorphosed and significantly deformed, whereas the quartz sandstone is not as metamorphosed. For example, micas in the quartz sandstone are relatively unaltered and plagioclase feldspar grains, some of which show good twinning, have higher calcium contents than those in the underlying sedimentary rocks where plagioclase is totally converted to albite. These observations suggest that the underlying sedimentary rocks

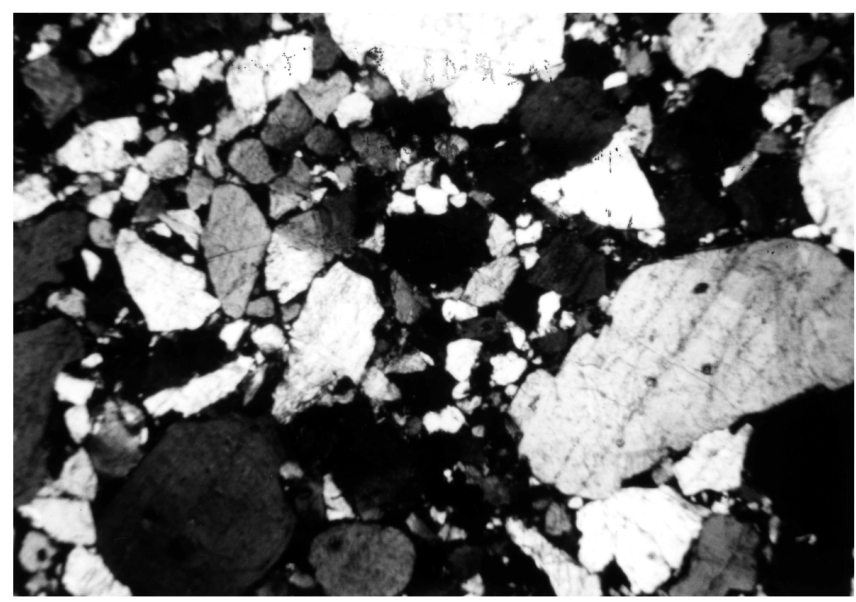

Figure 5. Thin section of quartz sandstone (Sample 152-917A-102R-3, 87$89 \mathrm{~cm}$ ). Most grains are composed of quartz with minor amounts of quartzite, feldspar, and mica. The grains have a wide range of rounding characteristics from angular to well rounded. Field of view is $0.2 \mathrm{~mm}$. Crossed polarized light. were metamorphosed, tilted, uplifted, and eroded before the quartz sandstone was deposited.

\section{MINERALOGY}

We examined 25 thin sections and completed modal analyses on 13 based on 500 point counts per section using the line method (Table 1). XRD data was collected from those same 13 samples (Table 2). XRD analysis was carried out with a Philips diffractometer using $\mathrm{CuK} \alpha$ radiation and a curved-crystal carbon monochromator. We scanned from $4^{\circ}$ to $70^{\circ} 2 \theta$ at a rate of $1 \% \mathrm{~min}$. Semi-quantitative mineral identification on the X-ray diffractograms was achieved by applying the mineral weighting factors of Cook et al. (1975).

The mineral assemblages are characteristic of the greenschist metamorphic facies (Plate 1). Major ubiquitous minerals are chlorite, albite, quartz, and epidote. White mica and graphite vary in content, being major contributors in some thin sections and minor in others. Pyrite, sphene/leucoxene, and biotite occur in trace amounts. Albite and minor amounts of chlorite make up most of the coarse-grained, light-colored beds. Chlorite replaces plagioclase feldspar and glass(?), fills burrows, and combines with albite and quartz in veins. Microcrystalline albite and quartz comprise most matrix components. Epidote and small irregular concentrations of sphene/leucoxene generally occur as broadly dispersed and optically irresolvable fine-grained masses. Graphite is abundant in the upper part of the core and, in general, becomes less abundant downcore; however, relatively high concentrations of graphite occur within black laminites in lower parts of the cored section.

Albite as a modal mineral ranges from about $1 \%$ to $49 \%$ by volume in the 13 thin sections that were point counted (Table 1). In most thin sections, where albite has a relatively low modal percentage,

Table 1. Modal analyses of thin sections.

\begin{tabular}{|c|c|c|c|c|c|c|c|c|c|}
\hline $\begin{array}{l}\text { Core, section, } \\
\text { interval }(\mathrm{cm})\end{array}$ & Chlorite & Albite & Quartz & Matrix & Epidote & Opaques & Muscovite & Biotite & Pyrite \\
\hline \multicolumn{10}{|l|}{ 152-917A- } \\
\hline 103R-1, 14-19 & 14.2 & 42.4 & 1.0 & & $\mathrm{t}$ & 42.4 & & & $\mathrm{t}$ \\
\hline 103R-1, 104-108 & 39.8 & 49.0 & 0.6 & & 7.2 & 2.4 & 1.0 & $\mathrm{t}$ & \\
\hline 103R-3, 1-8 & 63.2 & 30.2 & 2.2 & & 3.2 & 0.6 & 0.2 & & \\
\hline $104 \mathrm{R}-1,24-27$ & 49.0 & 11.5 & & 34.5 & 2.0 & 1.8 & 1.2 & & \\
\hline 104R-2, 74-77 & 44.8 & 4.6 & & 22.8 & 1.2 & 7.4 & 19.2 & & \\
\hline $105 \mathrm{R}-1,18-23$ & 39.0 & 13.8 & 0.6 & 36.2 & 0.4 & 8.6 & 1.4 & & \\
\hline $105 \mathrm{R}-1,129-132$ & 35.4 & 30.0 & 0.6 & 27.8 & 0.6 & 4.4 & 0.8 & & $\mathrm{t}$ \\
\hline 106R-1, 47-52 & 43.2 & 5.6 & & 33.4 & 1.6 & 9.6 & 6.6 & & \\
\hline 108R-1, 78-81 & 58.6 & 24.2 & & 7.2 & 2.0 & 8.0 & $\mathrm{t}$ & & \\
\hline $109 \mathrm{R}-1,47-50$ & 68.5 & 4.5 & & 12.8 & 0.8 & 6.0 & 7.4 & & \\
\hline 110R-1, 41-46 & 16.2 & 4.2 & 1.0 & 34.4 & 0.8 & 13.2 & 30.2 & & \\
\hline $110 \mathrm{R}-1,139-142$ & 3.4 & 10.2 & & 70.4 & 2.8 & 12.0 & 1.2 & $\mathrm{t}$ & \\
\hline 110R-2, 64-68 & 47.0 & 1.2 & & 23.0 & 1.2 & 23.2 & 4.4 & & \\
\hline
\end{tabular}

Notes: Some sections have rare sphene/leucoxene. $\mathrm{t}=$ trace.

Table 2. Mineralogy of metasedimentary rocks from XRD patterns.

\begin{tabular}{|c|c|c|c|c|c|c|c|c|}
\hline $\begin{array}{l}\text { Core, section, } \\
\text { interval }(\mathrm{cm})\end{array}$ & Chlorite & Albite & Quartz & Epidote & Grapite & Muscovite & Biotite & Pyrite \\
\hline \multicolumn{9}{|l|}{$152-917 \mathrm{~A}-$} \\
\hline $103 \mathrm{R}-1,14-19$ & $\mathrm{w}$ & $\mathrm{S}$ & $\mathrm{w}$ & $\mathrm{t}$ & w & $?$ & ? & $\mathrm{t}$ \\
\hline $103 \mathrm{R}-1,104-108$ & $\mathrm{~S}$ & $\mathrm{~S}$ & $\mathrm{w}$ & M & ? & $\mathrm{t}$ & $\mathrm{t}$ & $?$ \\
\hline 103R-3, 1-8 & $\mathrm{S}$ & $\mathrm{S}$ & $\mathrm{w}$ & M & $?$ & $\mathrm{t}$ & ? & $?$ \\
\hline $104 \mathrm{R}-1,24-27$ & $\mathrm{~S}$ & M & $\mathrm{M}$ & $\mathrm{w}$ & $\mathrm{t}$ & w & $?$ & ? \\
\hline 104R-2, 74-77 & $\mathrm{S}$ & M & M & $\mathrm{w}$ & $?$ & $\mathrm{~S}$ & ? & ? \\
\hline $105 \mathrm{R}-1,18-23$ & $\mathrm{~S}$ & $\mathrm{M}$ & $\mathrm{w}$ & $\mathrm{w}$ & $\mathrm{t}$ & $\mathrm{w}$ & ? & ? \\
\hline $105 \mathrm{R}-1,129-132$ & $\mathrm{~S}$ & $\mathrm{~S}$ & $\mathrm{M}$ & $\mathrm{w}$ & $\mathrm{t}$ & $\mathrm{w}$ & $?$ & $\mathrm{t}$ \\
\hline 106R-1, 47-52 & S & M & M & $\mathrm{W}$ & $\mathrm{t}$ & $\mathrm{M}$ & ? & ? \\
\hline $108 \mathrm{R}-1,78-81$ & $\mathrm{~S}$ & $\mathrm{~S}$ & $\mathrm{w}$ & $\mathrm{w}$ & $\mathrm{t}$ & $?$ & $?$ & ? \\
\hline $109 \mathrm{R}-1,47-50$ & $\mathrm{~S}$ & $\mathrm{M}$ & $\mathrm{w}$ & $\mathrm{w}$ & $\mathrm{t}$ & $\dot{\mathrm{M}}$ & ? & ? \\
\hline $110 \mathrm{R}-1,41-46$ & $\mathrm{M}$ & $\mathrm{w}$ & $\mathrm{S}$ & $\mathrm{w}$ & $\mathrm{w}$ & $\mathrm{S}$ & $?$ & ? \\
\hline $110 \mathrm{R}-1,139-152$ & $\mathrm{w}$ & $\mathrm{M}$ & $\mathrm{M}$ & $\mathrm{M}$ & $\mathrm{w}$ & $\mathrm{w}$ & ? & ? \\
\hline 110R-2, 64-68 & $\mathrm{S}$ & $\mathrm{M}$ & $\mathrm{S}$ & $\mathrm{w}$ & $\mathrm{w}$ & $\mathrm{M}$ & $\dot{?}$ & \\
\hline
\end{tabular}

Notes: Intensity of peaks: $\mathrm{S}=$ strong; $\mathrm{M}=$ moderate; $\mathrm{w}=$ weak; and $\mathrm{t}=$ trace. ? = not identified. 
XRD data indicate that the fine-grained matrix (originally glassy?) contains a significant amount of albite. The albite crystals are mostly untwinned (Pl. 1, Fig. 1). Albite replaces some pre-existing plagioclase feldspar crystals up to $3 \mathrm{~mm}$ in length; albite also occurs in grain interstices, within burrows, and in veins.

Quartz occurs rarely as discrete crystals or grains (Table 1); most quartz is secondary and confined to the fine-grained matrix and veins. Few, if any, of the present quartz grains are detrital. We suspect that very small detrital quartz grains recrystallized during metamorphism.

Chlorite is ubiquitous and of metamorphic origin. The spatial association of chlorite and albite indicates that they formed at the same time. Modal contents of chlorite range from about $3 \%$ to nearly $70 \%$. Chlorite fills interstices; is part of the fine-grained matrix; is the main constituent of most burrows; fills veins; and replaces primary feldspar crystals, glass(?), and ghost-like rock fragments (Pl. 1, Fig. 2). It is weakly birefringent. In plane-polarized light, colors range from medium dark green to very light green to colorless. Pleochroism is weak. In rare specimens where some of the iron is oxidized, colors of chlorites are various shades of orange and rusty red.

White mica is a common secondary mineral in the rocks; biotite was identified in two specimens (Tables 1,2). Although the white mica crystals are very small, we believe that it is muscovite. The crystals are light yellow and, in some thin sections, they display two interference colors under cross-polarized light. XRD patterns also indicate that muscovite occurs in the rocks (Table 2). Modal contents of white mica reach a maximum of about $30 \%$ in Sample 152-917A$110 \mathrm{R}-1,41-46 \mathrm{~cm}$. In some thin sections, the white mica grains are only weakly oriented $\{001\}$ parallel to bedding, and extinction varies throughout the specimen. In other thin sections, the white mica grains are oriented $\{001\}$ parallel to bedding, which causes simultaneous extinction on rotation of the microscope stage in cross-polarized light. White mica grains in burrows of one specimen apparently replaced chlorite (Beach and King, 1978; Dimberline, 1986) and are oriented $\{001\}$ randomly, whereas the very fine-grained white micas in the matrix parallel the bedding and exhibit simultaneous extinction.

Biotite (Pl. 1, Fig. 3) occurs in two of the 13 thin sections that were point counted (Table 1) and its presence was confirmed by XRD analyses. A light brown color, relatively strong pleochroism, and a high birefringence distinguish biotite from chlorite and white mica. The biotite is associated closely with, and apparently replaces, chlorite.

Epidote occurs as irregular, highly birefringent, and high-relief crystalline masses rather than as discrete crystals. Most of the epidote masses are scattered indiscriminately through the rocks. Epidote may have replaced foraminifers in some rock specimens (Pl. 1, Fig. 4). Rare masses of sphene and leucoxene, generally associated with epidote, also occur in some thin sections.

Most opaque material is graphite. The graphite (opaques in Table 1) apparently replaced organic carbon in the rocks. Modal contents of the opaque material range from $42 \%$ (top specimen) to less than $1 \%$. Because graphite tends to mask other minerals, the reported contents may be erroneously high in the modal data. Other opaque minerals are very rare and probably are iron/titanium oxides and iron sulfides. Small opaque oxides in some sections may be titanomagnetite. Rare pyrite occurs in the rocks, but it is difficult to distinguish optically from other opaque minerals because of its small grain size. XRD results, however, confirmed that pyrite is a rare constituent of the rocks.

XRD results (Table 2) complemented our microscope studies. We studied the relative peak intensities in each diffractogram and qualitatively assigned strong $(\mathrm{S})$, moderate $(\mathrm{M})$, weak $(\mathrm{w})$, and trace $(\mathrm{t})$ to the mineral contents. The relative peak intensities correlated fairly well with the modal abundances (compare Tables 1 and 2). Chlorite, albite, quartz, epidote, graphite, and muscovite are common minerals identified on the diffractograms. Biotite and pyrite are rare constituents. Graphite, although showing up in relatively high abundance in thin sections, shows only weak patterns on the diffractograms. This may in part be caused by interference of the graphite peaks with minor chlorite and quartz peaks and, in part, by the poor crystallinity of the graphite itself.

Almost all minerals are secondary. Only some of the opaque metallic oxides may be primary. Primary minerals, rock fragments, and volcanic glass(?) were replaced during diagenesis(?) and metamorphism. Primary plagioclase feldspar crystals are completely replaced by albite, chlorite, and epidote. White mica apparently replaced clay minerals and biotite replaced chlorite.

\section{ROCK CHEMISTRY Methods}

Major, minor, and trace elements were determined for two samples on board (Shipboard Scientific Party, 1994) using X-ray fluorescence (XRF) techniques, and 14 samples were analyzed at the U.S. Geological Survey (USGS) laboratories using XRF, inductively coupled plasma-atomic emission spectrometry (ICP-AES), instrumental neutron activation analysis (INAA), and wet chemical $\left(\mathrm{H}_{2} \mathrm{O}^{+}, \mathrm{H}_{2} \mathrm{O}^{-}\right.$, and $\mathrm{CO}_{2}$ ) techniques (Tables 3,4$)$. We do not duplicate the results from shipboard studies in the included tables, but we refer to the shipboard data in our discussions and plot some of the data in the figures. We also analyzed 13 samples for carbon and carbonate (Table 5) using the Coulometrics carbon-carbonate and total carbon apparatuses. Albite and chlorite were analyzed on an electron microprobe.

Major and minor elements (Table 3) were analyzed in the USGS laboratories by wavelength-dispersive XRF techniques that are discussed by Taggart et al. (1987). Wet chemical techniques for determining $\mathrm{H}_{2} \mathrm{O}^{+}, \mathrm{H}_{2} \mathrm{O}^{-}$, and $\mathrm{CO}_{2}$ contents were those of Jackson et al. (1987). The major and minor element oxide values were normalized to $100 \%$ after subtracting the water and $\mathrm{CO}_{2}$ contents.

Trace elements (Table 4) were determined by three analytical methods. Selected trace elements (Rb, Sr, Zr, Y, Ba, Ni, Zn, and Cr) were determined by energy dispersive XRF using the techniques of Johnson and King (1987). A problem element was $\mathrm{Nb}$, which was generally either at or below the detection limits $(<10 \mathrm{ppm})$ for the $\mathrm{XRF}$ procedures that were followed in the analyses. Therefore, we used ICP-AES for $\mathrm{Nb}$, but the values determined by this method are somewhat larger than those determined by the more precise XRF techniques that were used on board (Shipboard Scientific Party, 1994). ICP-AES was used for determining the amounts of $\mathrm{Cu}, \mathrm{Li}$, and $\mathrm{V}$ (Lichte et al., 1987). INAA techniques were used for other trace elements (Sc, Co, Cs, La, Ce, Nd, Sm, Eu, Tb, Yb, Lu, Hf, Ta, Th, and $\mathrm{U})$, following the procedures of Baedecker and McKown (1987). Sample aliquots for the INAA data were irradiated for $8 \mathrm{hr}$ in the USGS "TRIGA" reactor in Denver. After 6 days cooling time, the samples were counted four times within 8 weeks. Error limits for the elements are one standard deviation, based on counting statistics alone. Average counting error standard deviations $( \pm)$ for the rare earth elements $(\mathrm{N}=14)$ are $\mathrm{La}=4 \%, \mathrm{Ce}=5 \%, \mathrm{Nd}=13 \%, \mathrm{Sm}=3 \%$, $\mathrm{Eu}=5 \%, \mathrm{~Tb}=6 \%, \mathrm{Yb}=7 \%$, and $\mathrm{Lu}=6 \%$.

Carbon and carbonate contents (Table 5) were analyzed using coulometric techniques (Huffman, 1977; Engleman et al., 1985; Dean and Arthur, 1989). We ran standards every three analyses and are confident about the accuracy and precision of the data.

\section{Major and Minor Element Oxides}

Chemistry is a valuable tool for interpreting the original composition of sedimentary rocks and the mobility of various elements and ions. A complication in determining the original composition of the sediments is the mobility of materials, particularly of the large lithophile ions, which can be significant in sediments during diagenesis and metamorphism. For example, plagioclase feldspar crystals have been replaced completely by chlorite, albite, and epidote, thereby indicating large amounts of ion mobility. 
Table 3. Major- and minor-element oxides (in weight percent normalized to 100\%) of Hole 917A metasedimentary rocks.

\begin{tabular}{|c|c|c|c|c|c|c|c|c|c|c|c|c|c|c|c|}
\hline Core, section: & 103R-1 & 103R-1 & 103R-1 & $103 R-3$ & 104R-1 & $104 \mathrm{R}-2$ & $105 \mathrm{R}-1$ & $105 \mathrm{R}-1$ & 106R-1 & 108R-1 & 109R-1 & 110R-1 & 110R-1 & 110R-2 & \\
\hline Interval $(\mathrm{cm})$ : & $2-4$ & $14-19$ & 104-108 & $1-8$ & $24-27$ & $74-77$ & $18-23$ & $129-132$ & $47-52$ & $78-81$ & $47-50$ & $41-46$ & $139-142$ & $64-68$ & \\
\hline Depth (mbsf): & 826.92 & 827.04 & 827.94 & 829.46 & 831.74 & 833.78 & 836.68 & 837.79 & 841.67 & 856.58 & 860.77 & 865.71 & 866.69 & 867.44 & Average \\
\hline $\mathrm{SiO}_{2}$ & 57.37 & 56.28 & 52.61 & 51.15 & 55.12 & 53.98 & 51.74 & 54.21 & 53.01 & 50.04 & 50.72 & 60.08 & 55.46 & 60.26 & 54.38 \\
\hline $\mathrm{TiO}_{2}$ & 1.58 & 2.08 & 1.99 & 2.11 & 1.92 & 2.18 & 1.85 & 1.82 & 2.03 & 1.81 & 1.78 & 1.57 & 1.49 & 1.51 & 1.83 \\
\hline $\mathrm{Al}_{2} \mathrm{O}_{3}$ & 17.11 & 19.53 & 17.97 & 19.41 & 20.12 & 19.83 & 17.89 & 17.87 & 18.51 & 16.91 & 17.44 & 17.73 & 15.88 & 17.13 & 18.08 \\
\hline $\mathrm{Fe}_{2} \mathrm{O}_{3}$ & 3.27 & 1.77 & 3.44 & 4.73 & 5.95 & 2.74 & 3.66 & 3.11 & 2.76 & 3.11 & 3.18 & 1.95 & 2.76 & 1.64 & 3.15 \\
\hline $\mathrm{FeO}$ & 9.24 & 8.59 & 12.11 & 12.68 & 7.08 & 12.14 & 16.06 & 12.75 & 15.56 & 19.45 & 18.93 & 10.56 & 16.05 & 10.01 & 12.93 \\
\hline $\mathrm{MnO}$ & 0.17 & 0.22 & 0.27 & 0.31 & 0.15 & 0.24 & 0.26 & 0.19 & 0.28 & 0.41 & 0.43 & 0.23 & 0.36 & 0.34 & 0.28 \\
\hline $\mathrm{MgO}$ & 3.59 & 3.62 & 5.44 & 5.01 & 3.37 & 4.34 & 5.31 & 4.01 & 4.69 & 5.41 & 5.08 & 3.11 & 4.75 & 3.57 & 4.38 \\
\hline $\mathrm{CaO}$ & 1.91 & 0.16 & 1.25 & 0.29 & 0.42 & 0.14 & 0.28 & 0.67 & 0.07 & 0.23 & 0.06 & 0.28 & 0.23 & 0.42 & 0.46 \\
\hline $\mathrm{Na}_{2} \mathrm{O}$ & 4.86 & $\begin{array}{l}0.10 \\
7.66\end{array}$ & 4.34 & 3.09 & 4.41 & 2.03 & $\begin{array}{l}0.58 \\
1.58\end{array}$ & 4.47 & 1.57 & 2.21 & 1.83 & 2.43 & 2.78 & 4.23 & $\begin{array}{l}3.40 \\
3.39\end{array}$ \\
\hline $\begin{array}{l}\mathrm{Na}_{2} \mathrm{O} \\
\mathrm{K}_{2} \mathrm{O}\end{array}$ & $\begin{array}{l}0.00 \\
0.84\end{array}$ & $\begin{array}{l}.00 \\
0.09\end{array}$ & 0.07 & 1.22 & $\begin{array}{l}4.41 \\
1.46\end{array}$ & 2.32 & 1.18 & $\begin{array}{l}\text { l. } \\
0.41\end{array}$ & 1.52 & 0.04 & 0.65 & $\begin{array}{l}.45 \\
1.94\end{array}$ & 0.13 & 0.82 & 0.91 \\
\hline $\mathrm{P}_{2} \mathrm{O}_{5}$ & 0.06 & $?$ & 0.51 & $?$ & $?$ & 0.06 & $\begin{array}{l}1.10 \\
0.19\end{array}$ & $\begin{array}{l}0.41 \\
0.49\end{array}$ & $?$ & 0.18 & $?$ & 0.12 & 0.11 & 0.07 & 0.21 \\
\hline Total & 100.00 & 100.00 & 100.00 & 100.00 & 100.00 & 100.00 & 100.00 & 100.00 & 100.00 & 100.00 & 100.00 & 100.00 & 100.00 & 100.00 & 100.00 \\
\hline $\mathrm{H}_{2} \mathrm{O}^{+}$ & 4.01 & 3.52 & 5.53 & 5.86 & 5.35 & 5.42 & 6.14 & 4.54 & 5.59 & 6.07 & 5.84 & 4.05 & 5.08 & 3.75 & 5.05 \\
\hline $\mathrm{H}_{2} \mathrm{O}^{-}$ & 0.48 & 0.15 & 0.68 & 0.25 & 0.67 & 0.23 & 0.19 & 0.17 & 0.17 & 0.14 & 0.16 & 0.12 & 0.15 & 0.09 & 0.26 \\
\hline $\mathrm{CO}_{2}$ & 1.19 & 0.02 & 0.24 & 0.12 & 0.13 & $?$ & $?$ & & & $?$ & 0.01 & 0.07 & 0.05 & 0.02 & 0.21 \\
\hline
\end{tabular}

Notes: $\mathrm{mbsf}=$ meters below seafloor. $?=$ below detection limit. 
Table 4. Trace element contents of metasedimentary rocks, Hole 917A.

\begin{tabular}{|c|c|c|c|c|c|c|c|c|c|c|c|c|c|c|c|}
\hline $\begin{array}{l}\text { Core, section: } \\
\text { Interval }(\mathrm{cm}) \text { : }\end{array}$ & $\begin{array}{c}103 \mathrm{R}-1 \\
2-4\end{array}$ & $\begin{array}{c}103 R-1 \\
14-19\end{array}$ & $\begin{array}{c}103 R-1 \\
104-108\end{array}$ & $\begin{array}{c}103 R-3 \\
1-8\end{array}$ & $\begin{array}{l}104 \mathrm{R}-1 \\
24-27\end{array}$ & $\begin{array}{c}104 \mathrm{R}-2 \\
74-77\end{array}$ & $\begin{array}{c}105 \mathrm{R}-1 \\
18-23\end{array}$ & $\begin{array}{c}105 \mathrm{R}-1 \\
129-132\end{array}$ & $\begin{array}{c}106 \mathrm{R}-1 \\
47-52\end{array}$ & $\begin{array}{c}108 \mathrm{R}-1 \\
78-81\end{array}$ & $\begin{array}{c}109 \mathrm{R}-1 \\
47-50\end{array}$ & $\begin{array}{l}110 \mathrm{R}-1 \\
41-46\end{array}$ & $\begin{array}{c}110 \mathrm{R}-1 \\
139-142\end{array}$ & $\begin{array}{c}110 \mathrm{R}-2 \\
64-68\end{array}$ & Average \\
\hline $\mathrm{Sc}$ & 37 & 52 & 52 & 51 & 47 & 40 & 47 & 50 & 51 & 55 & 50 & 44 & 45 & 42 & 47 \\
\hline V & 230 & 320 & 320 & 360 & 320 & 270 & 260 & 280 & 340 & 290 & 260 & 250 & 250 & 240 & 285 \\
\hline $\mathrm{Cr}$ & 166 & 192 & 162 & 174 & 250 & 160 & 136 & 138 & 154 & 120 & 118 & 140 & 124 & 144 & 156 \\
\hline Co & 35 & 32 & 48 & 85 & 44 & 65 & 90 & 81 & 60 & 72 & 57 & 67 & 37 & 45 & 58 \\
\hline $\mathrm{Ni}$ & 100 & 128 & 126 & 235 & 96 & 120 & 106 & 124 & 140 & 112 & 85 & 77 & 116 & 134 & 121 \\
\hline $\mathrm{Cu}$ & 66 & ? & 130 & 9 & 5 & 100 & 260 & 170 & 5 & 1 & $?$ & 610 & 13 & 3 & 114 \\
\hline $\mathrm{Zn}$ & 42 & 25 & 32 & 28 & 16 & 22 & 32 & 21 & 40 & 58 & 56 & 40 & 108 & 200 & 51 \\
\hline $\mathrm{Rb}$ & 20 & ? & $?$ & 37 & 35 & 77 & 39 & 19 & 40 & ? & 22 & 57 & 12 & 23 & 35 \\
\hline $\mathrm{Li}$ & 31 & 40 & 51 & 78 & 49 & 82 & 93 & 61 & 70 & 82 & 73 & 80 & 56 & 64 & 65 \\
\hline $\mathrm{Ba}$ & 220 & 40 & 30 & 295 & 172 & 485 & 330 & 114 & 280 & ? & 118 & 200 & ? & 186 & 206 \\
\hline $\mathrm{Sr}$ & 64 & 40 & 55 & 24 & 28 & 23 & 13 & 31 & 10 & 17 & ? & 26 & 16 & 94 & 34 \\
\hline $\mathrm{Y}$ & 25 & 14 & 50 & 27 & 20 & 25 & 24 & 42 & 20 & 47 & 16 & 17 & 23 & 17 & 26 \\
\hline $\mathrm{Zr}$ & 95 & 124 & 112 & 136 & 114 & 134 & 114 & 110 & 128 & 112 & 104 & 104 & 96 & 94 & 113 \\
\hline $\mathrm{Nb}$ & 12 & 16 & 11 & 17 & 14 & 17 & 14 & 12 & 15 & 15 & 12 & 12 & 13 & 12 & 14 \\
\hline $\mathrm{La}$ & 14.4 & 4.45 & 20.7 & 16.01 & 6.41 & 6.8 & 7.06 & 17.3 & 10.09 & 13.2 & 6.3 & 18.1 & 3.97 & 4.04 & 10.63 \\
\hline $\mathrm{Ce}$ & 29.7 & 10.3 & 48 & 29.8 & 12.3 & 13.4 & 15.8 & 41.1 & 21.1 & 29.7 & 13.2 & 34.1 & 9.2 & 8.1 & 22.56 \\
\hline $\mathrm{Nd}$ & 14.9 & 5.9 & 32.2 & 16.5 & 8.9 & 5.6 & 10.3 & 24.01 & 11.01 & 20.2 & 7.2 & 13.9 & 7.5 & 5.6 & 13.12 \\
\hline $\mathrm{Sm}$ & 3.51 & 1.65 & 9.77 & 4.39 & 2.05 & 2.06 & 3.3 & 8.32 & 2.74 & 8.82 & 1.87 & 3.16 & 2.15 & 1.36 & 3.94 \\
\hline $\mathrm{Eu}$ & 0.65 & 0.43 & 1.96 & 1.05 & 0.63 & 0.52 & 0.57 & 1.3 & 0.72 & 4.6 & 0.64 & 0.97 & 1.19 & 0.76 & 1.14 \\
\hline $\mathrm{Tb}$ & 0.59 & 0.35 & 1.72 & 0.7 & 0.39 & 0.47 & 0.7 & 1.51 & 0.54 & 2.18 & 0.42 & 0.42 & 0.6 & 0.36 & 0.78 \\
\hline $\mathrm{Yb}$ & 2.99 & 2.44 & 4.64 & 3.44 & 2.51 & 3.12 & 2.51 & 3.53 & 2.82 & 5.6 & 2.24 & 2.58 & 2.52 & 2.41 & 3.1 \\
\hline $\mathrm{Lu}$ & 0.45 & 0.43 & 0.66 & 0.56 & 0.37 & 0.5 & 0.41 & 0.52 & 0.44 & 0.64 & 0.38 & 0.42 & 0.43 & 0.37 & 0.47 \\
\hline $\mathrm{Hf}$ & 2.51 & 3.3 & 3.17 & 3.58 & 3.07 & 3.6 & 3.04 & 3.07 & 3.43 & 3.22 & 3.02 & 2.78 & 2.75 & 2.5 & 3.07 \\
\hline $\mathrm{Ta}$ & 0.49 & 0.6 & 0.61 & 0.63 & 0.61 & 0.7 & 0.58 & 0.56 & 0.65 & 0.55 & 0.54 & 0.5 & 0.52 & 0.5 & 0.57 \\
\hline Th & 3.16 & 2.9 & 2.75 & 3.5 & 3.25 & 3.04 & 2.7 & 3.51 & 3.07 & 2.72 & 2.96 & 4.3 & 3.03 & 3.02 & 3.14 \\
\hline $\mathrm{U}$ & 0.71 & 0.63 & 0.73 & 1.21 & 0.81 & 0.9 & 0.74 & 0.74 & 0.72 & 0.83 & 0.63 & 0.84 & 0.51 & 0.78 & 0.77 \\
\hline $\mathrm{Zr} / \mathrm{Nb}$ & 7.92 & 7.75 & 10.18 & 8.01 & 8.14 & 7.89 & 7.86 & 9.17 & 8.53 & 7.47 & 8.67 & 8.67 & 7.39 & 7.83 & 8.25 \\
\hline $\mathrm{Ba} / \mathrm{Zr}$ & 2.31 & 0.32 & 0.27 & 2.17 & 1.51 & 3.62 & 2.9 & 1.04 & 2.19 & NA & 1.15 & 1.92 & NA & 1.98 & 1.78 \\
\hline
\end{tabular}

Notes: V, Cu, and Nb by ICP-AES (P.H. Biggs, analyst). Cr, Ni, Zn, Rb, Ba, Sr, Y, and Zr by XRF, wavelength dispersive methods (J. Kent, analyst). Remainder by INAA (G.A. Wandless, analyst). Values of elements in parts per million $(\mathrm{ppm}) . ?=$ below detection limit. NA = not analyzed.

Table 5. Carbon and carbonate contents.

\begin{tabular}{lccccc}
\hline $\begin{array}{c}\text { Core, section, } \\
\text { interval (cm) }\end{array}$ & $\begin{array}{c}\text { Depth } \\
\text { (mbsf) }\end{array}$ & $\begin{array}{c}\mathrm{TC} \\
(\mathrm{wt} \%)\end{array}$ & $\begin{array}{c}\mathrm{IC} \\
(\mathrm{wt} \%)\end{array}$ & $\begin{array}{c}\mathrm{TOC} \\
(\mathrm{wt} \%)\end{array}$ & $\begin{array}{c}\mathrm{CaCO}_{3} \\
(\mathrm{wt} \%)\end{array}$ \\
\hline 152-917A- & & & & & \\
103R-1, 14-19 & 827.04 & 3.29 & 0.01 & 3.28 & 0.08 \\
103R-1, 104-108 & 827.94 & 2.19 & 0.03 & 2.16 & 0.25 \\
103R-3, 1-8 & 829.91 & 0.36 & 0.05 & 0.31 & 0.42 \\
104R-1, 24-27 & 831.74 & 0.70 & 0.08 & 0.62 & 0.67 \\
104R-2, 74-77 & 833.74 & 0.51 & 0.00 & 0.51 & 0.00 \\
105R-1, 18-23 & 836.68 & 0.49 & 0.01 & 0.48 & 0.08 \\
105R-1, 129-132 & 837.79 & 0.68 & 0.01 & 0.67 & 0.08 \\
106R-1, 47-52 & 841.67 & 0.57 & 0.00 & 0.57 & 0.00 \\
108R-1, 78-81 & 856.58 & 0.58 & 0.00 & 0.58 & 0.00 \\
109R-1, 47-50 & 860.77 & 1.00 & 0.01 & 0.99 & 0.08 \\
110R-1, 41-46 & 865.71 & 0.39 & 0.02 & 0.37 & 0.16 \\
110R-1, 139-142 & 866.69 & 1.20 & 0.01 & 1.19 & 0.08 \\
110R-2, 64-68 & 867.44 & 1.14 & 0.00 & 1.14 & 0.00 \\
\hline
\end{tabular}

Notes: $\mathrm{TC}=$ total carbon, $\mathrm{IC}=$ inorganic carbon, and $\mathrm{TOC}=$ total organic carbon .

Major element oxides (Table 3) show a range in values related not only to the composition of the original materials, but also to fluid flow and metasomatic transfer during diagenetic and metamorphic processes. The mobilities of $\mathrm{SiO}_{2}, \mathrm{Al}_{2} \mathrm{O}_{3}$, and $\mathrm{CaO}$, and the alkalis $\mathrm{Na}_{2} \mathrm{O}$ and $\mathrm{K}_{2} \mathrm{O}$ probably were high. We suspect that the weight percent of $\mathrm{Na}_{2} \mathrm{O}$ and $\mathrm{K}_{2} \mathrm{O}$ changed in all samples. $\mathrm{H}_{2} \mathrm{O}$ values (3.52-6.14 wt $\% \mathrm{H}_{2} \mathrm{O}^{+}$and $0.09-0.68 \mathrm{wt} \% \mathrm{H}_{2} \mathrm{O}^{-}$) indicate the amount of bound or essential and nonessential water, respectively, in the samples (Jackson et al., 1987). High $\mathrm{Fe}_{2} \mathrm{O}_{3} / \mathrm{FeO}$ ratios, such as that of Sample 152-917A-104R-1, 24-27 cm (ratio of 0.84), reflect the relatively higher amounts of oxidation in some chlorite lattices. A low ratio, such as that in Sample 152-917A-110R-1, 139-142 cm (ratio of 0.17 ), is probably closer to the original iron-oxide ratio of the sediments.

Silica $\left(\mathrm{SiO}_{2}\right)$ content (Table 3) ranges from a normalized low of $50.04 \mathrm{wt} \%$ to a normalized high of $60.62 \mathrm{wt} \%$ (average $=54.38$ ). The two highest values occur lower in the hole and probably reflect higher quartz contents, particularly as shown by modal and $\mathrm{X}$-ray diffraction analyses of Sample 152-917A-110R-1, 41-46 cm (Tables 1, 2). Titanium is a relatively immobile element during metamorphism, and $\mathrm{TiO}_{2}$ contents may be close to the original values. $\mathrm{Al}_{2} \mathrm{O}_{3}$ values (av- erage $=18.08 \mathrm{wt} \%$ ) most likely reflect a high amount of plagioclase feldspar, glassy(?) volcanic ash, and clay minerals in the original sediments.

Calcium, sodium, potassium, and phosphorous are relatively mobile ions during low-grade metamorphism. Low $\mathrm{Ca}$ and high $\mathrm{Na}$ contents reflect sodium for calcium replacement in plagioclase feldspar. There must have been, however, a net transfer of $\mathrm{Ca}$ out of the sediments during metamorphism, probably in fluids that either reached the seafloor or precipitated elsewhere in the sediment pile as calcite in veins. Calcium presently is most likely bound in epidote, and sodium is in albite. Potassium abundance correlates with white mica (muscovite) content (compare Tables 1, 2, and 3). Potassium probably was concentrated first in detrital clay minerals and finally in the white mica during metamorphism. Phosphorous abundances are highly irregular.

\section{Trace Elements}

The original composition of many metamorphosed flow rocks and plutonic rocks can be recognized by their trace element contents, particularly of the incompatible elements group (e.g., $\mathrm{Hf}, \mathrm{Nb}, \mathrm{Ta}, \mathrm{Y}$, and $\mathrm{Zr}$ ) and the heavy rare earth elements ( $\mathrm{Yb}$ and $\mathrm{Lu})$, and by selected ratios of these elements. Unfortunately, metasedimentary rock source materials are difficult to interpret by chemical means alone because of the probable complexity of sediment sources. Interpretations are further complicated by ion mobilities that occur during diagenesis and metamorphism, although the incompatible elements are thought to be least susceptible to transport (Pearce and Cann, 1973). In the metasedimentary rocks recovered from Hole 917A, petrographic, mineralogic, and major element chemical criteria discussed above suggest that many were originally mafic (to intermediate) volcanic sediments. Therefore, we presume that some of the trace elements can be used to characterize the original composition (and possibly the tectonic setting) of the volcanic contributions.

The large, low-valence cations $\mathrm{Ba}, \mathrm{Li}, \mathrm{Rb}$, and $\mathrm{Sr}$ behave similarly to $\mathrm{K}$ and $\mathrm{Ca}$, which we showed above to have been very mobile during the alteration processes. Ba values have a wide range, from below the instrumental detection limit of about $30 \mathrm{ppm}$ to $485 \mathrm{ppm}$ 
(average is $206 \mathrm{ppm}$ for 12 samples that have values greater than 30 $\mathrm{ppm}$ ). Li abundance ranges from 31 to $93 \mathrm{ppm}($ average $=65) . \mathrm{Rb}$ values range from below detection limits of $10 \mathrm{ppm}$ to $77 \mathrm{ppm}$ (average for 11 samples is $35 \mathrm{ppm}$ ), and $\mathrm{Sr}$ contents range from below detection limit of 10 to $64 \mathrm{ppm}$ (average for 13 samples is $34 \mathrm{ppm}$ ). Ba, $\mathrm{Rb}$, and $\mathrm{Li}$ values are higher than those from ocean floor basalts (Basaltic Volcanism Study Project, 1981) and correlate in part with K abundance, thereby reflecting the elements' close association with potassium and with muscovite contents in the metasedimentary rocks. Sr is depleted, similar to Ca. Relatively high (compared to contents in basaltic rocks) contents of $\mathrm{Ba}, \mathrm{Li}$, and $\mathrm{Rb}$ imply an outside source for those elements, either from metamorphic (hydrothermal) fluids or from the erosion of continental crystalline rocks.

Amounts of the compatible (ferromagnesian) elements $\mathrm{Ni}, \mathrm{Co}, \mathrm{V}$, $\mathrm{Sc}$, and $\mathrm{Cr}$ may closely reflect their original contents (Table 4). Ni ranges from 77 to $235 \mathrm{ppm}$ (average $=121$ ), Co from 32 to $90 \mathrm{ppm}$ $($ average $=58), \mathrm{V}$ from 230 to $360 \mathrm{ppm}($ average $=285), \mathrm{Sc}$ from 37 to $55 \mathrm{ppm}$ (average $=47$ ), and $\mathrm{Cr}$ from 118 to $250 \mathrm{ppm}$ (average $=$ 156). Their abundances are, in fact, very similar to those in most mafic volcanic rocks from a wide variety of tectonic settings and ages, particularly the ocean floor basalts (Basaltic Volcanism Study Project, 1981). The compatible elements, in parallel with magnesium and iron, may have migrated first into smectite (if the sediments were indeed volcaniclastic) during diagenesis and then into chlorite during metamorphism.

The incompatible high-valence elements of the titanium group (Hf, Ta, Y, Zr and $\mathrm{Nb}$ ) are not as susceptible to mobility during seafloor alteration and metamorphism as the compatible elements (Pearce and Cann, 1973). Hf values range from 2.51 to $4.3 \mathrm{ppm}$ (average $=2.7)$; Ta amounts range from 0.49 to $0.7 \mathrm{ppm}$ (average $=$ 0.57 ); $\mathrm{Y}$ contents range from 14 to $50 \mathrm{ppm}$ (average $=26$ ); and $\mathrm{Zr}$ contents range from 94 to $136 \mathrm{ppm}$ (average $=113$ ). $\mathrm{Nb}$ has relatively low values; XRF results from two samples on board the ship are 8 and 9 ppm (Shipboard Scientific Party, 1994). Shore-based laboratory XRF results show contents of 10 ppm or less for the 14 samples (Vallier, unpubl. data), whereas ICP-AES results are higher and $\mathrm{Nb}$ contents range from 11 to $17 \mathrm{ppm}$ (average $=14$ ). $\mathrm{Zr} / \mathrm{Nb}$ ratios are about 14 (shipboard determinations) and 7.9 (shore-based determinations) respectively; both ratios are low compared to those from most samples in the overlying basalt/dacite sequence in Hole 917A (Shipboard Scientific Party, 1994). The titanium group trace elements have contents and ratios that are similar to seafloor basalt (Basaltic Volcanism Study Project, 1981), suggesting that the original sediments were derived from a basaltic terrane (Figs. 6, 7).

Th and $U$ contents are high relative to most seafloor basalt (Basaltic Volcanism Study Project, 1981). Th contents range from 2.7 to 4.3 ppm (average $=3.14$ ) and $U$ values range from 0.51 to $1.21 \mathrm{ppm}$ (average $=0.77$ ). The relatively high contents are not correlative with carbon contents and, thereby, may be caused by enrichment from hydrothermal fluids or by contamination from the erosion of continental source rocks.

The relatively constant $\mathrm{Th} / \mathrm{Ta}$ ratios range from 4.3 to 8.6 (average $=5.5$ ). If the samples were basalt, rather than metamorphosed sedimentary rocks, we would conclude that they were from an arc or backarc setting based on these high ratios. Plotted points on a Hf/3Th-Ta diagram (Wood, 1980) also suggest that the sediments were derived from volcanic rocks that formed along a destructive plate margin (Fig. 8). The tight clustering of points in Figure 8 indicates that relative mobility of the three ions was negligible. The quantities of those three elements may be very close to the original values.

The rare earth element contents and diagrams (Table 4; Fig. 9) probably reflect both the composition of the original sediments and some alteration effects. The heavy rare earth elements (HREE), Yb and $\mathrm{Lu}$, have chondrite-normalized values very similar to seafloor (MORB, island arc, and ocean island) tholeiites and their associated more fractionated rocks (Basaltic Volcanism Study Project, 1981). The light rare earth elements (LREE) have a wider range of values

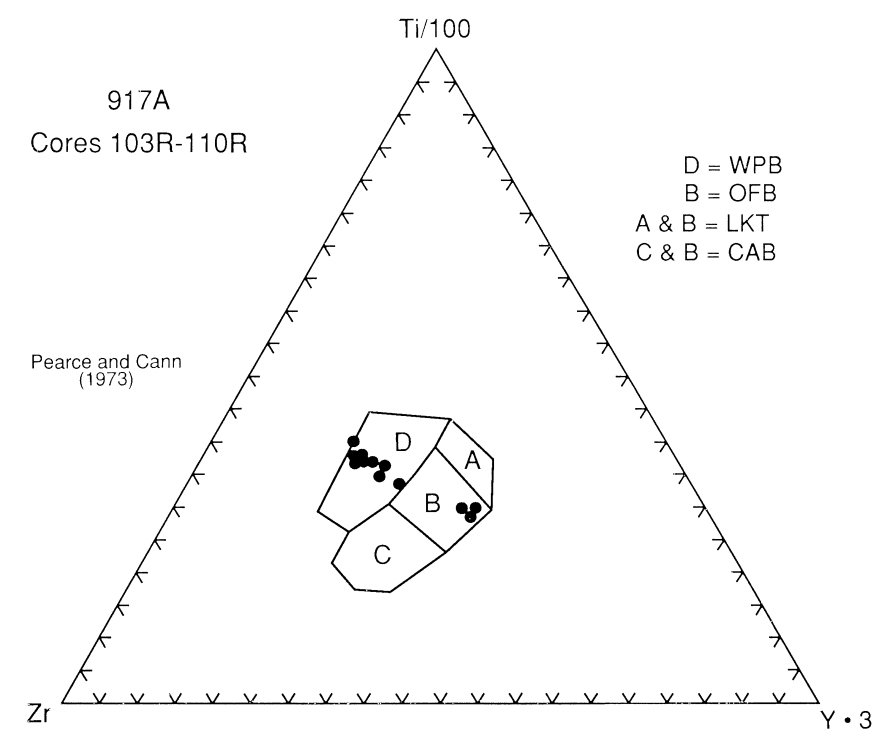

Figure 6. Ti-Y-Zr diagram (Pearce and Cann, 1973) showing the compositional similarity between the metasedimentary rocks and seafloor basalt. "Within-plate" basalts (WPB) plot in field D, ocean-floor basalts (OFB) in field $\mathrm{B}$, low-potassium tholeiites (LKT) in fields A and B, calc-alkali basalts $(\mathrm{CAB})$ in fields $\mathrm{C}$ and $\mathrm{B}$.

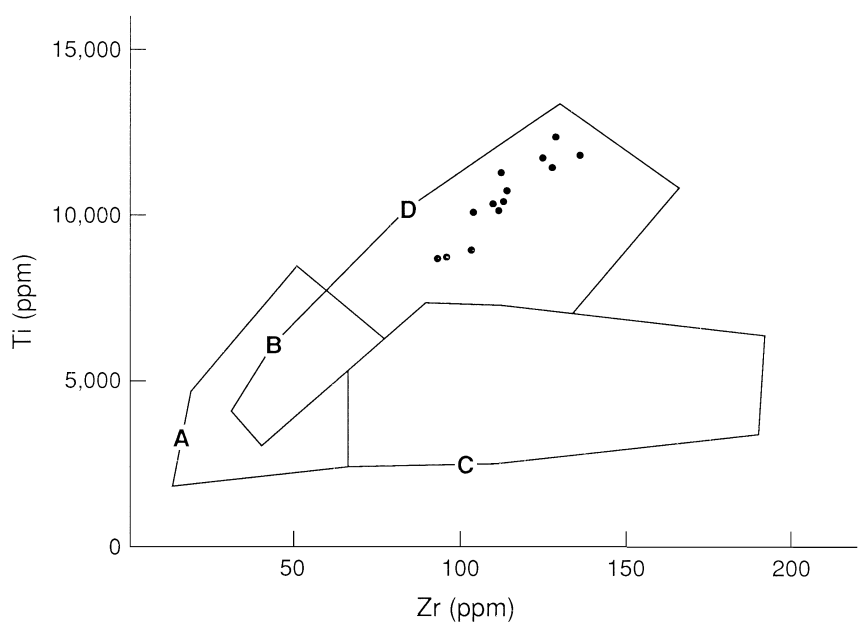

Figure 7. Ti-Zr diagram (Pearce and Cann, 1973) showing similarities between the metasedimentary rocks from Hole $917 \mathrm{~A}$ and seafloor basalt. Ocean-floor basalts (OFB) plot in fields $\mathrm{D}$ and $\mathrm{B}$, low-potassium tholeiites (LKT) plot in fields A and B, and calc-alkali basalts (CAB) in fields C and B.

and probably reflect some ion mobility. The LREE La, Ce, and $\mathrm{Nd}$ have a wide range of values (Table 4): La between about 4 and 21 ppm $($ average $=10.6)$; Ce between about 8 and 48 ppm $($ average $=$ 22.6); and Nd between 5.6 and $32 \mathrm{ppm}$ (average $=13.1$ ). There is no doubt that the LREE were mobile during metamorphism (and during diagenesis?) as already pointed out by other workers (e.g., Hellman and Henderson, 1977). A mixed volcanic and continental source for the sediments also could account for the irregularities.

$\mathrm{Cu}$ has a wide range of values (below detection limit of $1 \mathrm{ppm}$ to $610 \mathrm{ppm}$ with an average of $114 \mathrm{ppm}$ for 12 samples). The high $\mathrm{Cu}$ content in Sample 152-917A-110R-1, 41-46 cm, is associated with relatively high values of $\mathrm{Rb}, \mathrm{LREE}, \mathrm{Th}$, and $\mathrm{U}$. An INAA analysis of this sample (Vallier, unpubl. data; not in Table 4) shows anomalously high gold $(28 \pm 12 \mathrm{ppb})$ and arsenic $(64.6 \pm 3 \mathrm{ppm})$ contents, suggesting a hydrothermal source for those elements. 
Figure 8. Hf/3-Th-Ta diagram of Wood (1980). $A=N-$ type MORB, B = E-type MORB, C = within-plate basalts, and $\mathrm{D}=$ magma series at destructive plate margins. Note the tight clustering of samples in field D.

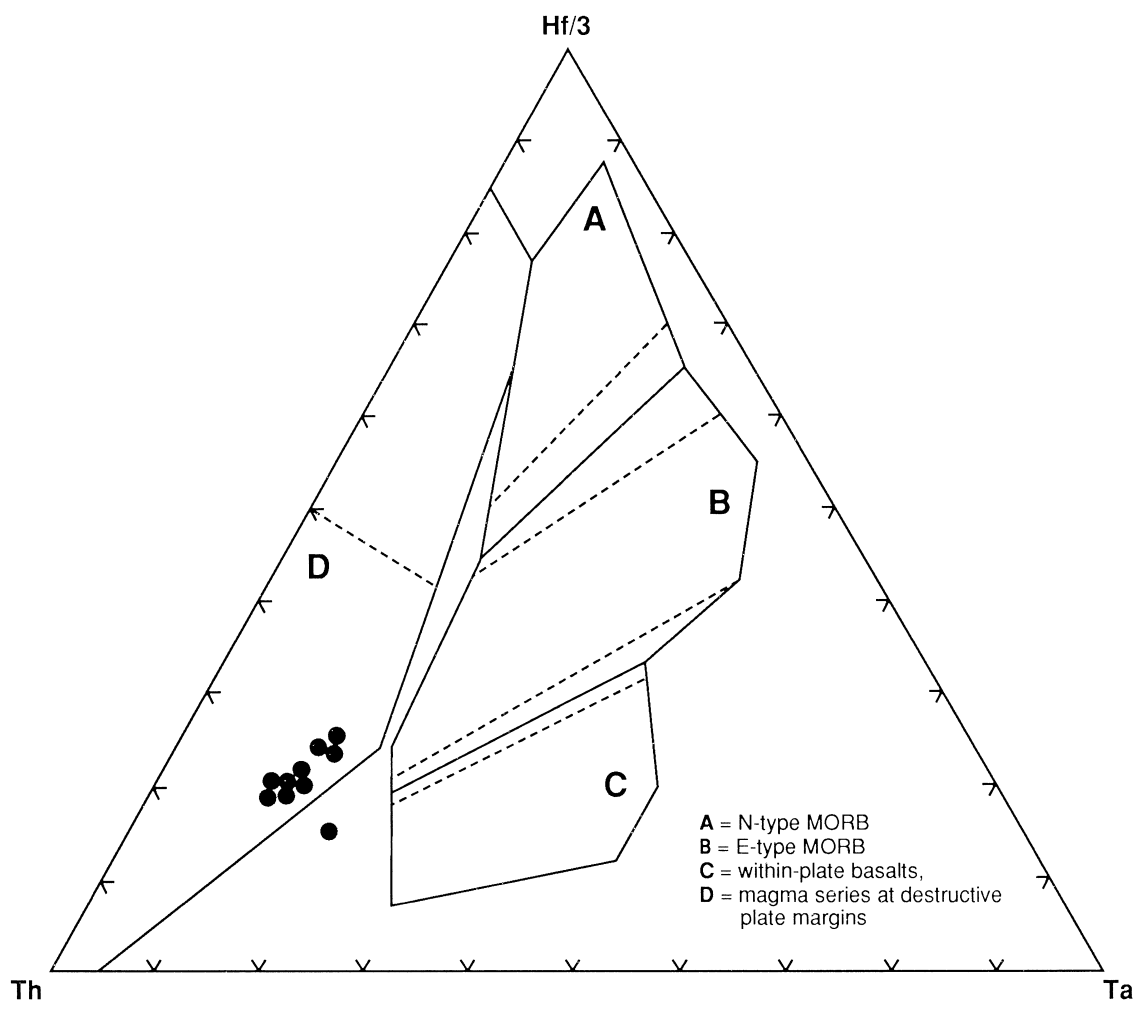

compositions and high abundances of chlorite in the rocks suggest that the mineral formed primarily from mafic volcanic sediments.

\section{METAMORPHIC PROCESSES AND P/T CONDITIONS}

\section{MINERAL CHEMISTRY}

We analyzed albite and chlorite (Tables 6,7) using a JEOL 8900 microprobe. Five grains of albite were analyzed in Sample 152917A-103R-1, 119-123 cm, and six in Sample 152-917A-104R-1, 129-130 cm (Table 6). Standards used for the analyses were albite for $\mathrm{Si}, \mathrm{Al}$, and $\mathrm{Na}$, synthetic anorthite $\left(\mathrm{An}_{100}\right)$ for $\mathrm{Ca}$, orthoclase for $\mathrm{K}$, and synthetic fayalite for Fe. Analyses were completed using a 15 $\mathrm{kV}$ beam, $25 \mathrm{nA}$ beam current as measured on a Faraday cup, and with a slightly defocused beam $(\sim 10 \mu \mathrm{m})$ to reduce mobilization of $\mathrm{Na}$. Standards used for the chlorite analyses were Kakanui hornblende for $\mathrm{Si}, \mathrm{Al}$, and $\mathrm{Ca}$; biotite for $\mathrm{Mg}$ and $\mathrm{K}$; crocidolite for $\mathrm{Fe}$ and $\mathrm{Na}$; chromite for $\mathrm{Cr}$; and synthetic oxides for $\mathrm{Ti}$ and $\mathrm{Mn}$. Beam conditions were as above.

Albite in the studied samples is nearly pure, with $\mathrm{Ab}$ contents ranging from 98.0 to $99.6 \mathrm{wt} \%$. An contents are less than $1.0 \mathrm{wt} \%$ and Or contents range from 0.3 to $1.2 \mathrm{wt} \%$. Based on low to intermediate $\mathrm{SiO}_{2}$ contents (Table 3 ) in the bulk rock samples and their relatively high iron and magnesium contents, we presume that the original feldspars were more calcium-rich, probably in the labradorite to andesine range, and conclude that the albite is entirely secondary. Textural evidence confirms that the albite (and chlorite) formed after deposition of the sediments.

Chlorite analyses show variable oxide contents (Table 7), although they plot (Hey, 1954) rather consistently in the relatively high-Fe fields of ripidolite, pycnochlorite, brunsvigite, and diabantite (Fig. 10). High $\mathrm{Fe}$ and $\mathrm{Mg}$ contents in the chlorite grains indicate that this phase holds most of the iron and magnesium. Furthermore, the interpreted from albite and chlorite chemistries and from graphite crystallinity. We have shown that albite, chlorite, epidote, muscovite, biotite, graphite, and quartz crystallized during metamorphism. Iron and magnesium ions were plentiful and migrated easily into the chlorite lattices. Origin of the excess $\mathrm{Na}$ that was necessary to form nearly pure albite is a problem; an outside source (open system) may be needed to account for its abundance. We suspect that high-salinity water was available in the sediment pile (e.g., Battles and Barton, 1995) and ascribe to a method of sodium concentration similar to the layered double-diffusive convection method proposed by Bischoff and Rosenbauer (1989), which they used to explain some of the metamorphic mineral assemblages observed in rocks from mid-ocean ridges and ophiolites.

High heat flow and an abundance of saline water would enhance ion mobility and free interchange, particularly of large, low valence ions like $\mathrm{Ca}$ and $\mathrm{Na}$. The $\mathrm{Ca}$, freed from plagioclase feldspar (and foraminifers?), migrated easily. The remaining $\mathrm{Ca}$ is bound up mostly in epidote. Most potassium was incorporated into muscovite. The trace elements pretty well mimic many of the major elements with the compatible trace elements moving with $\mathrm{Mg}$ and $\mathrm{Fe}$, the large ions like $\mathrm{Ba}, \mathrm{Sr}$, and $\mathrm{Rb}$ moving with $\mathrm{Ca}$ and $\mathrm{K}$, and the incompatible highfield-strength elements staying with Ti. The chalcophile elements such as $\mathrm{Cu}, \mathrm{Zn}$, and As are enriched in some specimens, possibly as a result of hydrothermal transfer.

Albite is stable throughout most of the greenschist facies to relatively high temperatures. It allows calcium for sodium exchange at lower amphibolite facies temperatures, which may be in the range of $450^{\circ}-500^{\circ} \mathrm{C}$, depending on pressure and water content. Therefore,
Ranges in pressures and temperatures $(\mathrm{P} / \mathrm{T})$ of metamorphism are 


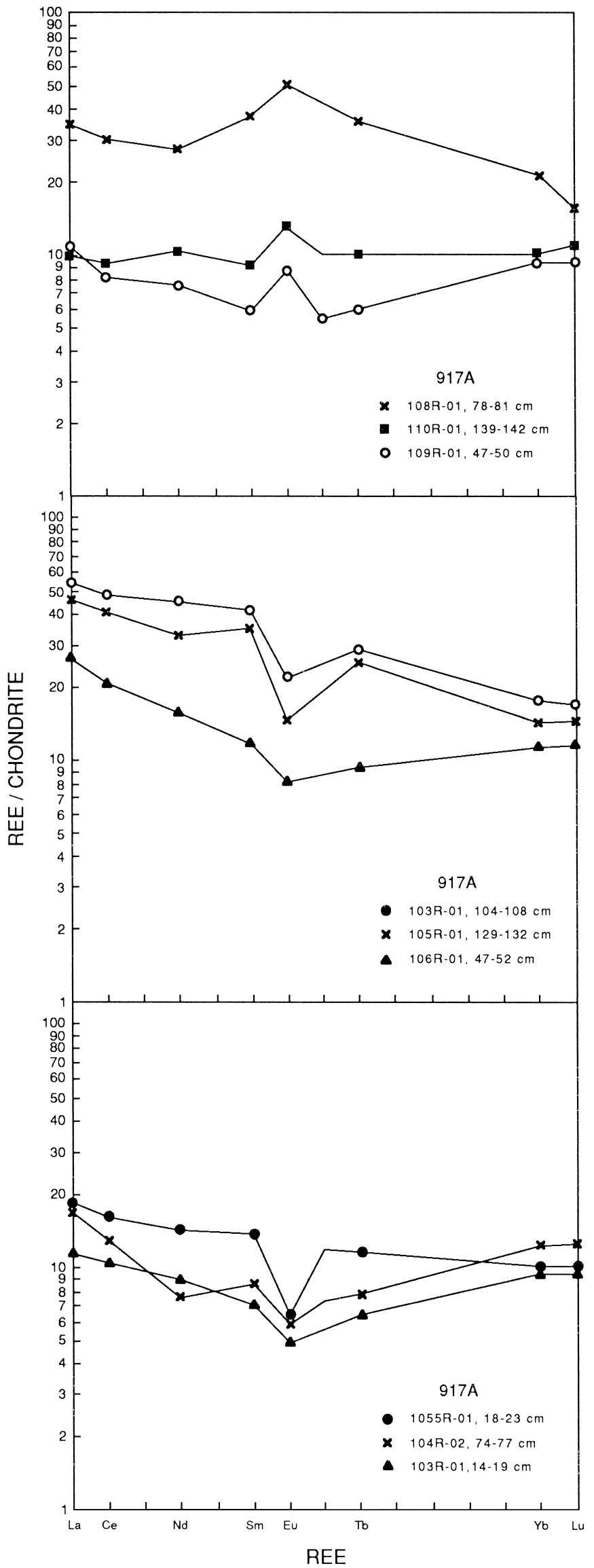

the presence of albite in these rocks is not necessarily diagnostic of temperatures, except that it was probably lower than $450^{\circ}-500^{\circ} \mathrm{C}$.

Chlorite geothermometers proposed in recent years are reviewed by de Caritat et al. (1993). We used the empirical calibration of Cathelineau and Nieva (1985), as revised by Cathelineau (1988), to estimate the temperature of equilibration of chlorite in the metasedimentary rocks of Hole 917A. As Schiffman and Fridleifsson (1991) cautioned, this thermometer should only be applied to nearly pure chlorites with very low amounts of interlayered smectite. Bettison and Schiffman (1988) showed that chlorite containing more than 6.25 Si cations per formula unit (based on 28 oxygens) include interlayered smectite. Therefore, we have not calculated temperatures (Table 7) for those analyses containing more than $6.20 \mathrm{Si}$ cations. Our chlorite analyses yield average temperatures of $296^{\circ} \mathrm{C}$ for Sample 152917A-103R-1, 119-123 cm; $300^{\circ} \mathrm{C}$ for Sample 152-917A-104R-1, $129-130 \mathrm{~cm}$; and $356^{\circ} \mathrm{C}$ for Sample 152-917A-108R-1, 36-39 cm. Chlorite in Sample 152-917A-108R-1, 36-39 cm, has the most consistently low $\mathrm{Si}$ cations per formula unit and correspondingly low $\mathrm{Na}$, $\mathrm{K}$, and Ca cations. Therefore, the average temperature of $356^{\circ} \mathrm{C}$ obtained for this sample is considered to be the best estimate of temperature in Hole 917A, based solely on chlorite composition. The highest temperatures obtained $\left(396^{\circ}\right.$ and $\left.402^{\circ} \mathrm{C}\right)$ may be more realistic, however, considering the presence of biotite in some of the samples.

All of the organic matter was reduced to graphite during hightemperature metamorphism. Rock-Eval measurements showed no significant hydrocarbon generation by pyrolysis, which confirms the very high maturity of the organic materials. We were able to identify no macerals at all and, therefore, were not able to obtain information on the origin and structure of the organic material. Graphite is not an extremely informative mineral with respect to metamorphic conditions because of the complex relationships of $\mathrm{H}_{2} \mathrm{O}, \mathrm{CH}_{4}, \mathrm{CO}_{2}$, and $f \mathrm{O}_{2}$ (Holloway, 1984). The original carbon apparently can recrystallize to graphite under a wide range of $\mathrm{P} / \mathrm{T}$ conditions. Holloway (1984) found that in progressive metamorphism of high-pressure schists (possibly not applicable for the samples from Hole 917A), vitrinite and graphite occur together from $250^{\circ}$ to $350^{\circ} \mathrm{C}$ and that above $350^{\circ} \mathrm{C}$ only graphite remains - which persists at least to $450^{\circ} \mathrm{C}$, the limit of experimental data at that time.

The minimum temperature for the graphite crystallization in Hole $917 \mathrm{~A}$ metasedimentary rocks is about $350^{\circ} \mathrm{C}$. The absence of any remains of organic particles, however, and the sole presence of graphite argues for a higher temperature, perhaps as high as $450^{\circ} \mathrm{C}$.

Greenschist facies metamorphism has a wide temperature and pressure range, within the window defined by about $300^{\circ}-500^{\circ} \mathrm{C}$ and 2-9 Kb (Winkler, 1976; Turner, 1981). The presence of metamorphic biotite in two of the samples suggests temperatures in the higher range. We suspect that burial of the sediment pile was not too great, which implies low-pressure conditions and a relatively high geothermal gradient. There is no doubt that more data are needed to precisely define the temperature and pressure conditions of metamorphism. Based on our rather limited amount of data, however, we conclude that the temperature of metamorphism was in the $350^{\circ}-450^{\circ} \mathrm{C}$ range and that the pressure was near the lower end of the greenschist window, probably in the $2-4 \mathrm{~kb}$ range.

Figure 9. Rare earth element diagrams for nine rocks from Hole 917A showing (bottom) patterns very similar to MORB with $\mathrm{La}_{N} / \mathrm{Lu}_{\mathrm{N}}$ ratios close to 1 and a negative Eu anomaly; (middle) rocks with patterns that have $\mathrm{La}_{N} / \mathrm{Lu}_{\mathrm{N}}$ ratios $>>1$, indicating probable addition of the light rare earth elements during weathering and metamorphism, along with a negative Eu anomaly; and (top) rare earth patterns with $\mathrm{La}_{N} / \mathrm{Lu}_{\mathrm{N}}$ ratios close to 1 , but with a positive Eu anomaly. Normalizing values, based on analyses of the Leedey chondrite (Masuda et al., 1973), are the following: $\mathrm{La}=0.378, \mathrm{Ce}=0.976, \mathrm{Nd}=0.716$, $\mathrm{Sm}=0.230, \mathrm{Eu}=0.0866, \mathrm{Yb}=0.249$, and $\mathrm{Lu}=0.0387 . \mathrm{Tb}$ value of 0.0589 from R. Kay (pers. comm., 1984) based on isotope dilution methods on the Leedey chondrite. 
Table 6. Albite chemistry.

\begin{tabular}{|c|c|c|c|c|c|c|c|c|c|c|}
\hline Sample & $\mathrm{SiO}_{2}$ & $\mathrm{Al}_{2} \mathrm{O}_{3}$ & $\mathrm{FeO}$ & $\mathrm{CaO}$ & $\mathrm{Na}_{2} \mathrm{O}$ & $\mathrm{K}_{2} \mathrm{O}$ & Total & & & \\
\hline 103R \#4 & 69.9 & 20.5 & 0.096 & 0.073 & 11.5 & 0.08 & 102.1 & & & \\
\hline 103R \#5 & 68.8 & 20.0 & 0.289 & 0.092 & 11.3 & 0.103 & 100.5 & & & \\
\hline $103 \mathrm{R} \# 6$ & 68.8 & 20.7 & 0.249 & 0.174 & 11.3 & 0.206 & 101.5 & & & \\
\hline $103 R \#$ & $\begin{array}{l}69.0 \\
69.2\end{array}$ & 20.5 & 0.068 & 0.079 & 11.3 & 0.201 & 101.4 & & & \\
\hline $103 \mathrm{R} \# 8$ & 69.1 & 19.6 & 0.105 & 0.097 & 11.8 & 0.065 & 100.8 & & & \\
\hline 104R \#1 & 69.6 & 20.2 & 0.043 & 0.074 & 11.6 & 0.061 & 101.5 & & & \\
\hline 104R \#2 & 69.7 & 20.2 & 0.044 & 0.072 & 11.8 & 0.135 & 102 & & & \\
\hline $104 \mathrm{R} \# 3$ & 69.2 & 20.4 & 0.046 & 0.089 & 11.8 & 0.067 & 101.6 & & & \\
\hline $104 \mathrm{R} \# 4$ & 69.1 & 20.1 & $\begin{array}{l}.0 .040 \\
0.159\end{array}$ & 0.088 & $\begin{array}{l}11.0 \\
11.3\end{array}$ & 0.111 & 100.8 & & & \\
\hline $104 \mathrm{R} \# 5$ & 69.2 & 19.8 & 0.067 & 0.073 & 11.8 & 0.08 & 101.1 & & & \\
\hline 104R \#6 & 69.9 & 20.2 & 0.074 & 0.024 & 11.7 & 0.052 & 101.9 & & & \\
\hline Sample & $\mathrm{SiO}_{2}$ & $\mathrm{Al}_{2} \mathrm{O}_{3}$ & $\mathrm{FeO}$ & $\mathrm{CaO}$ & $\mathrm{Na}_{2} \mathrm{O}$ & $\mathrm{K}_{2} \mathrm{O}$ & Total & $\mathrm{Ab}$ & An & Or \\
\hline 103R \#4 & 11.94 & 4.126 & 0.014 & 0.013 & 3.809 & 0.017 & 19.92 & 0.349 & 99.2 & 0.453 \\
\hline $103 \mathrm{R} \# 5$ & 11.95 & 4.092 & 0.042 & 0.017 & 3.805 & 0.023 & 19.92 & 0.445 & 98.96 & 0.593 \\
\hline $103 R \# 6$ & 11.86 & 4.206 & 0.036 & 0.032 & 3.767 & 0.045 & 19.95 & 0.835 & 97.99 & 1.178 \\
\hline $103 \mathrm{R} \# 7$ & 11.91 & 4.162 & 0.01 & 0.015 & 3.777 & 0.044 & 19.92 & 0.381 & 98.47 & 1.15 \\
\hline $103 \mathrm{R} \# 8$ & 11.98 & 4.012 & 0.015 & 0.018 & 3.961 & 0.014 & & 0.451 & 99.19 & 0.361 \\
\hline 104R \#1 & 11.96 & 4.083 & 0.006 & 0.014 & 3.857 & 0.013 & 19.93 & 0.35 & 99.31 & 0.345 \\
\hline $104 \mathrm{R} \# 2$ & 11.95 & 4.07 & 0.006 & 0.013 & 3.922 & 0.03 & 19.99 & 0.333 & 98.92 & 0.744 \\
\hline $104 \mathrm{R} \# 3$ & 11.91 & 4.129 & 0.007 & 0.016 & 3.919 & 0.015 & 19.99 & 0.415 & 99.21 & 0.372 \\
\hline $104 \mathrm{R} \# 4$ & 11.96 & 4.094 & 0.023 & 0.016 & 3.786 & 0.025 & 19.9 & 0.426 & 98.93 & 0.64 \\
\hline $104 \mathrm{R} \# 5$ & 11.97 & 4.033 & 0.01 & 0.014 & 3.964 & 0.018 & 20.01 & 0.338 & 99.22 & 0.441 \\
\hline $104 \mathrm{R} \# 6$ & 11.96 & 4.078 & 0.011 & 0.004 & 3.892 & 0.011 & 19.95 & 0.113 & 99.6 & 0.292 \\
\hline
\end{tabular}

Note: Structural formulas (bottom half of the table) based on eight oxygens. Samples are 152-917A-103R-1, 119-123 cm, and 152-917A$104 \mathrm{R}-1,129-130 \mathrm{~cm}$. Ab = albite, An= anorthite, Or = orthoclase.

\section{DISCUSSION OF AGE AND CHARACTERISTICS OF ORIGINAL SEDIMENTS}

We don't know the depositional age of the metasedimentary rocks from Hole 917A and have found, in the literature, no unequivocal correlative rocks either in East Greenland or in other outcrops around the rim of the North Atlantic Ocean. Our attempts at dating the metamorphism by radiometric methods failed. All fossils were destroyed by metamorphic heat. Furthermore, many of the original sediment characteristics were destroyed during metamorphism and we have been compelled to interpret their origin from mineralogies and chemical data of bulk rock and mineral samples. Our major interpretations are discussed below.

1. The metasedimentary rocks are older than the Paleocene basalt flows and older than the quartz sandstone that lies between the metasedimentary rocks and basalt flows. The quartz sandstone is essentially undeformed, unfossiliferous, and apparently not as metamorphosed as the underlying rocks. The most likely correlative unit for the metasedimentary rocks is the Late Cretaceous to early Danian Ryberg Formation (Soper et al., 1976; Nielsen et al., 1981) that is exposed in eastern Greenland, $600 \mathrm{~km}$ north of Site 917. Recent field work by members of the Danish Lithosphere Centre (H.C. Larsen, pers. comm., 1995) strengthen this interpretation. Carbon-rich rocks, very similar to those cored in the lower part of Hole 917A, were mapped and collected from outcrops of the Ryberg Formation. The carbon-rich rocks are overlain by quartz conglomerate and quartz sandstone. Studies are currently underway to compare the onland rocks with the metasedimentary rocks from Hole 917A. If this proposed correlation is correct, then the metasedimentary rocks we recovered from Hole 917A are probably Late Cretaceous (Maastrichtian) and early Paleocene in age.

2 . The sedimentary rocks were tilted and eroded before the quartz sandstone was deposited and the basalt flows accumulated. Also, the degree of metamorphism within the sediments is considerably higher than that seen in the basalt (Demant et al., this volume), suggesting an earlier (and stronger) metamorphism of the sediments. The rocks do not have a secondary cleavage $\left(S_{2}\right)$ that would indicate a major folding event. Rather, the early tilting may have been caused by a rift- ing or extensional event during early spreading in the North Atlantic Ocean basin.

3. Textures, mineralogy, and chemistry suggest that at least some of the sediments were derived from a volcanic source terrane that had either a very low crystalline rock (coarse-grained and quartz-feldspathic plutonic and metamorphic rocks) component-or none at all. We suspect that the relatively high contents of iron, magnesium, titanium, and manganese reflect the original mafic composition of the volcanic components and that the original sediments consisted, in part, of basaltic glass(?) and basaltic rock fragments.

4. Nielsen et al. (1981) described a Late Cretaceous basin (including Ryberg Formation) along the East Greenland Margin, which may be related to the basin where the Site 917 sediments accumulated. We wonder, however, about the tectonics responsible for basin development along the East Greenland Margin. The basin may not have been able to develop until significant spreading was occurring in the Labrador Sea and the resultant strain was accommodated along the East Greenland Margin. According to Srivastava and Verhoef (1992), spreading in the Labrador Sea started around magnetic Chron 31, whereas Chalmers and Lausen (1995) interpreted breakup to around Chron 27 time.

5. Metamorphism probably occurred in the Late Cretaceous-earliest Tertiary interval (before deposition of the quartz sandstone and extrusion of basalt). Although we cannot be sure that the quartz sandstone was not affected by the metamorphic event, we know that the basalt, even in its lowest part, is not metamorphosed to the greenschist facies (Demant et al., this volume) and, thereby, we conclude that the basalt was not affected by the same thermal event.

\section{CONCLUSIONS}

We propose that the sediments were deposited: (1) in latest Cretaceous (probably Maastrichtian) and earliest Paleocene time; (2) within a graben or half-graben that formed in response to rifting of the East Greenland Margin; (3) either far from a continental source terrane or in a location that was somehow protected from the influx of abundant continentally derived sediments; and (4) with a significant quantity of volcanic components. 
Table 7. Chlorite chemistry.

\begin{tabular}{|c|c|c|c|c|c|c|c|c|c|c|c|c|c|c|c|c|c|c|c|c|}
\hline \multirow[t]{2}{*}{ Sample: } & \multicolumn{12}{|c|}{ 152- 917A-103R-1, 119-123 cm } & \multicolumn{8}{|c|}{ 152-917A-104R-1, $129-130 \mathrm{~cm}$} \\
\hline & 1 & 2 & 3 & 4 & 5 & 6 & 7 & 8 & 9 & 10 & 11 & Avg. & 1 & 2 & 3 & 4 & 5 & 6 & 7 & 8 \\
\hline $\mathrm{SiO}_{2}$ & 27.0 & 27.7 & 27.4 & 31.5 & 31.1 & 30.2 & 29.7 & 31.4 & 30.5 & 27.2 & 27.8 & 29.2 & 30.8 & 31.2 & 32.7 & 34.9 & 30.7 & 30.5 & 35.8 & 34.5 \\
\hline $\mathrm{Al}_{2} \mathrm{O}_{3}$ & 21.7 & 20.1 & 22.2 & 19.4 & 22.1 & 19.2 & 18.8 & 20.3 & 20.0 & 20.5 & 20.8 & 20.5 & 23.4 & 23.8 & 23.6 & 22.0 & 24.2 & 22.6 & 21.5 & 18.6 \\
\hline $\mathrm{TiO}_{2}$ & 0.071 & 0.101 & 0.039 & 0.036 & 0.045 & 0.041 & 0.075 & 0.048 & 0.126 & 0.005 & 0.077 & 0.060 & 0.017 & 0.049 & 0.076 & 0.057 & 0.092 & 0.05 & 0.409 & 0.122 \\
\hline $\mathrm{FeO}$ & 25.7 & 27.2 & 25.5 & 26.9 & 26.4 & 28.3 & 28.2 & 26.6 & 26.9 & 27.4 & 26.9 & 26.9 & 23.6 & 22.7 & 23.3 & 20.5 & 21.8 & 23.9 & 23.4 & 24.8 \\
\hline $\mathrm{MnO}$ & 0.198 & 0.373 & 0.309 & 0.326 & 0.416 & 0.359 & 0.353 & 0.361 & 0.373 & 0.407 & 0.342 & 0.347 & 0.347 & 0.298 & 0.253 & 0.326 & 0.29 & 0.317 & 0.305 & 0.299 \\
\hline $\mathrm{MgO}$ & 15.1 & 12.6 & 13.7 & 11.0 & 9.42 & 11.4 & 11.9 & 10.7 & 9.87 & 13.3 & 12.5 & 11.9 & 9.48 & 9.62 & 8.09 & 9.04 & 8.84 & 10.7 & 8.19 & 8.77 \\
\hline $\mathrm{CaO}$ & 0.052 & 0.133 & 0.036 & 0.234 & 0.170 & 0.240 & 0.223 & 0.203 & 0.243 & 0.087 & 0.073 & 0.154 & 0.136 & 0.147 & 0.153 & 0.156 & 0.105 & 0.096 & 0.112 & 0.177 \\
\hline $\mathrm{Na}_{2} \mathrm{O}$ & & 0.027 & 0.027 & 0.061 & 0.04 & 0.043 & 0.025 & 0.053 & 0.108 & 0.027 & 0.019 & 0.039 & 0.044 & 0.057 & 0.069 & 0.047 & 0.042 & 0.028 & 0.040 & 0.050 \\
\hline $\mathrm{K}_{2} \mathrm{O}$ & 0.022 & 0.036 & 0.022 & 0.089 & 0.096 & 0.058 & 0.072 & 0.122 & 0.205 & 0.022 & 0.031 & 0.070 & 0.521 & 0.307 & 0.964 & 0.475 & 0.561 & 0.686 & 0.969 & 1.418 \\
\hline $\mathrm{Cr}_{2} \mathrm{O}_{3}$ & 0 & 0 & 0 & 0.034 & 0.023 & 0.065 & 0.032 & 0.086 & 0.059 & 0.002 & 0.004 & 0.028 & 0.015 & 0 & 0.015 & 0.012 & 0.012 & 0 & 0 & 0.012 \\
\hline Total & 89.78 & 88.40 & 89.18 & 89.61 & 89.75 & 89.81 & 89.39 & 89.91 & 88.34 & 88.88 & 88.48 & 89.23 & 88.33 & 88.20 & 89.30 & 87.46 & 86.70 & 88.94 & 90.76 & 88.82 \\
\hline $\mathrm{Si}$ & 5.530 & 5.825 & 5.629 & 6.445 & 6.304 & 6.228 & 6.178 & 6.377 & 6.339 & 5.694 & 5.810 & 6.034 & 6.265 & 6.301 & 6.544 & 6.968 & 6.294 & 6.198 & 7.010 & 7.034 \\
\hline $\mathrm{Al}_{4}$ & 2.470 & 2.175 & 2.371 & 1.555 & 1.696 & 1.772 & 1.822 & 1.623 & 1.661 & 2.306 & 2.190 & 1.966 & 1.735 & 1.699 & 1.456 & 1.032 & 1.7 & 1.802 & 0.990 & 0.966 \\
\hline $\mathrm{Al}_{6}$ & $\begin{array}{l}2.766 \\
5\end{array}$ & 2.808 & $\begin{array}{l}3.008 \\
5.30\end{array}$ & 3.124 & $\begin{array}{l}3.586 \\
5.82\end{array}$ & $\begin{array}{r}2.892 \\
4641\end{array}$ & 2.781 & 3.248 & 3.246 & 2.741 & 2.924 & $\begin{array}{l}3.013 \\
4.070\end{array}$ & $\begin{array}{l}3.871 \\
5.605\end{array}$ & $\begin{array}{l}3.980 \\
5670\end{array}$ & $\begin{array}{l}4.115 \\
5571\end{array}$ & $\begin{array}{l}4.143 \\
5.175\end{array}$ & $\begin{array}{l}4.1 \\
58\end{array}$ & $\begin{array}{l}3.617 \\
540\end{array}$ & 3.973 & 3.510 \\
\hline $\mathrm{Al}$ & 5.236 & 4.983 & 5.380 & 4.680 & 5.283 & 4.664 & 4.603 & 4.871 & 4.907 & 5.046 & 5.114 & 4.979 & 5.605 & 5.679 & 5.571 & 5.175 & 5.8 & 5.419 & 4.963 & 4.476 \\
\hline $\mathrm{Ti}$ & 0.011 & 0.016 & 0.006 & 0.006 & 0.007 & 0.006 & 0.012 & 0.007 & 0.020 & 0.001 & 0.012 & 0.009 & 0.003 & 0.007 & 0.011 & 0.0 & 0.0 & 0.0 & 0.0 & 0.019 \\
\hline $\mathrm{Fe}_{\mathrm{t}}$ & 4 & 4.780 & 4.3 & 4.5 & 4.472 & 4.891 & 4.909 & 4.520 & 4.678 & 4.7 & 4.698 & 4.6 & 4.0 & 3.8 & 3.9 & 3.4 & 3.7 & 4.0 & 3.8 & 4.230 \\
\hline $\mathrm{Mn}$ & 034 & 0.0 & 0.0 & 0.056 & 0.071 & 0.06 & 0.062 & 0.062 & 0.066 & 0.0 & 0.06 & 0.0 & 0.060 & 0.051 & 0.0 & 0.0 & 0.0 & 0.0 & 0.0 & 0.052 \\
\hline $\mathrm{Mg}$ & 600 & 3.9 & 4.198 & 3.34 & 2.848 & 3.4 & 3.672 & 3.251 & 3.06 & 4.1 & 3.90 & 3.6 & 2.87 & 2.897 & 2.4 & 2.6 & 2.7 & 3.2 & 2.3 & 2.663 \\
\hline $\mathrm{Ca}$ & 0.011 & 0.030 & 0.008 & 0.051 & 0.037 & 0.053 & 0.050 & 0.044 & 0.054 & 0.020 & 0.01 & 0.0 & 0.030 & 0.032 & 0.033 & 0.0 & 0.0 & 0.0 & 0.023 & 0.039 \\
\hline $\mathrm{Na}$ & 0.000 & 0.011 & 0.011 & 0.024 & 0.016 & 0.017 & 0.010 & 0.021 & 0.044 & 0.011 & 0.008 & 0.01 & 0.017 & 0.022 & 0.027 & 0.018 & 0.017 & 0.011 & 0.015 & 0.020 \\
\hline $\mathrm{K}$ & 0.006 & 0.010 & 0.006 & 0.023 & 0.025 & 0.015 & 0.019 & 0.032 & 0.054 & 0.006 & 0.008 & 0.019 & 0.135 & 0.079 & 0.246 & 0.121 & 0.147 & 0.178 & 0.242 & 0.369 \\
\hline $\mathrm{Cr}$ & 0.000 & 0.000 & 0.000 & 0.005 & 0.004 & 0.011 & 0.005 & 0.014 & 0.010 & 0.000 & 0.001 & 0.005 & 0.002 & 0.000 & 0.002 & 0.002 & 0.002 & 0.000 & 0.000 & 0.002 \\
\hline Total & 19.844 & 19.678 & 19.684 & 19.231 & 19.066 & 19.445 & 19.520 & 19.200 & 19.232 & 19.790 & 19.628 & 19.482 & 19.005 & 18.903 & 18.794 & 18.505 & 18.844 & 19.179 & 18.577 & 18.903 \\
\hline $\mathrm{Al}$ & 36.74 & 36.32 & 38.51 & 37.08 & 41.92 & 35.73 & 34.91 & 38.53 & 38.80 & 36.08 & 37.30 & 37.42 & 44.87 & 45.76 & 46.86 & 45.81 & 47.63 & 42.64 & 44.41 & 39.37 \\
\hline $\mathrm{Fe}$ & & & & & & 37.47 & 37.23 & 35.75 & 36.99 & 34.25 & 34.26 & 34.94 & 32.12 & 30.90 & 32.85 & & 30.41 & 31.99 & & 37.21 \\
\hline $\mathrm{Mg}$ & 32.28 & 28.84 & 30.05 & 26.48 & 22.60 & 26.79 & 27.85 & 25.72 & 24.20 & 29.67 & 28.44 & 27.64 & 23.01 & 23.34 & 20.29 & 23.83 & 21.96 & 25.37 & 21.37 & 23.42 \\
\hline$T\left({ }^{\circ} \mathrm{C}\right)$ & 336 & 288 & 320 & & & & 231 & & & 309 & 291 & & & & & & & 228 & & \\
\hline
\end{tabular}


Table 7 (continued).

\begin{tabular}{|c|c|c|c|c|c|c|c|c|c|c|c|c|c|c|c|c|c|c|c|c|c|}
\hline \multirow[t]{2}{*}{ Sample: } & \multicolumn{8}{|c|}{$152-917 \mathrm{~A}-104 \mathrm{R}-1,129-130 \mathrm{~cm}$} & \multicolumn{13}{|c|}{$152-917 \mathrm{~A}-108 \mathrm{R}-1,36-39 \mathrm{~cm}$} \\
\hline & 9 & 10 & 11 & 12 & 13 & 14 & 15 & Avg. & 2 & 4 & 5 & 6 & 7 & 8 & 9 & 10 & 11 & 12 & 13 & 14 & avg. \\
\hline $\mathrm{SiO}_{2}$ & 29.7 & 25.2 & 31.1 & 26.8 & 30.9 & 27.7 & 31.5 & 30.9 & 24.6 & 24.2 & 29.8 & 24.1 & 28.5 & 25.4 & 25.2 & 25.5 & 25.3 & 23.9 & 23.8 & 24.2 & 25.4 \\
\hline & & & & & & & & & & 24.4 & 22.3 & & 22.8 & 21.5 & 21.2 & 20.9 & 21.3 & 23.7 & & & 22.6 \\
\hline $\mathrm{TiO}_{2}$ & 0.052 & 0.114 & 0.032 & 0.082 & 0.091 & 0.097 & 0.012 & 0.090 & 0.039 & 0.1 & 0.06 & 0.069 & 0.113 & 0.051 & 0.03 & 0.079 & 0.028 & 0.13 & 0.082 & 0.057 & 0.070 \\
\hline $\mathrm{FeO}$ & 25.7 & 28.9 & 23.2 & 27.0 & 25.0 & 26.5 & 23.7 & 24.3 & 33.4 & 31.0 & 28.4 & 31.1 & 29.1 & 33.4 & 33.4 & 33.3 & 33.5 & 30.8 & 33.8 & 33.4 & 32.0 \\
\hline $\mathrm{MnO}$ & .379 & 0.288 & 0.219 & 0.345 & 0.228 & 0.265 & 0.228 & 0.292 & 0.569 & 0.621 & 0.525 & 0.57 & 0.599 & 0.668 & 0.634 & 0.698 & 0.683 & 0.549 & 0.614 & 0.602 & 0.611 \\
\hline & & 11.6 & 8.07 & 11.4 & & 10.2 & 8.10 & 9.41 & 8.63 & 9.56 & 8.32 & & & & 9.00 & 9.35 & & 9.15 & 8.12 & 8.47 & 8.90 \\
\hline & 064 & 0.022 & 0.098 & 0.050 & 0.1 & 0.059 & 0.223 & 0. & & 0.008 & 0.015 & 0 & & 0.006 & 0.0 & 0. & & & 0.011 & & 0.009 \\
\hline & & 0.006 & 0.047 & 0.009 & 0.0 & & 0.0 & 0. & 0.0 & 0. & 0 & 0 & 0.014 & 0.000 & 0.0 & 0.8 & & & 0 & & 0.005 \\
\hline & 1.263 & 0.044 & 0.529 & 0.144 & 1.4 & 0.3 & 0.507 & 0.6 & 0.053 & 0.045 & 0.041 & 0.055 & 0.029 & 0.018 & 0.027 & 0.0 & & & 0.026 & & 0.037 \\
\hline & & & & & & & & & & & & & & & & & & & & & 0.020 \\
\hline Total & 89.92 & 90.32 & 88.43 & 89.50 & 89.18 & $\begin{array}{l}0.001 \\
89.15\end{array}$ & 88.25 & 88.88 & 89.62 & 89.98 & 89.47 & 89.18 & 90.37 & 90.02 & 89.57 & $\begin{array}{l}0.096 \\
\end{array}$ & 89.86 & $\begin{array}{l}08.001 \\
88.36\end{array}$ & 90.35 & 89.73 & 89.71 \\
\hline $\mathrm{Si}$ & 6.067 & 5.234 & 6.274 & 5.538 & 6.315 & 5.710 & 6.395 & 6.282 & 5.298 & 5.118 & 6.149 & 5.140 & 5.858 & 5.447 & 5.435 & 5.471 & 5.440 & 5.159 & 5.089 & 5.215 & 5.405 \\
\hline & & & & & & & & & & & & & & & & & & & & & \\
\hline A & & 3.117 & 4.251 & 3.302 & 3.700 & 3.5 & 4.092 & 3.79 & 2.961 & 3.198 & 3.571 & 3.2 & 3.384 & 2.869 & 2.8 & 2.7 & 2.845 & & & & 3.081 \\
\hline & & 5.883 & 5.976 & 5.764 & 5.385 & & & & & & & & & & & & & & & & 5.676 \\
\hline $\mathrm{T}$ & & & 0.00 & 0.01 & & & & & & & & & & & & & & & & & 0.011 \\
\hline & & & & 4.65 & & & & & & & & & & & & & & & & & \\
\hline & & 0.051 & & & & & & & & & & & & & & & & & & & \\
\hline $\mathrm{Mg}$ & & 3.584 & 2.427 & 3.50 & 2.7 & & 2.4 & 2.8 & & & & & & & & & & & & & 2.824 \\
\hline $\mathrm{Ca}$ & 0.0 & 0.00 & 0.0 & 0.01 & 0.0 & 0.0 & 0.0 & 0.0 & 0.0 & 0. & 0.0 & & & 0.0 & 0.0 & & 0.002 & & & & \\
\hline & & & & & & & & & & & & & & & & & & & & & \\
\hline & & 0. & & & & & & & & & & & & & & & & & & & \\
\hline & & & & & & & & & & & & & & & & & & & & & \\
\hline Total & $\begin{array}{l}0.399 \\
\end{array}$ & 19.813 & 18.810 & 19.587 & 19.179 & 19.412 & 18.836 & 19.045 & $\begin{array}{r}0.869 \\
19.869\end{array}$ & 19.833 & 19.136 & 19.811 & 19.368 & 19.836 & 19.870 & 19.874 & 19.856 & 19.817 & 19.887 & 19.884 & 19.750 \\
\hline & & & & & & & & & & & & & & & & & & & & & \\
\hline & & & & & & & & & & & & & & & & & & & & & \\
\hline $\mathrm{Mg}$ & 24.19 & 24.74 & 19.70 & 25.16 & 21.97 & 23.20 & 20.13 & 22.83 & 19.17 & 20.67 & 19.86 & 19.94 & 21.25 & 19.96 & 20.21 & 20.97 & 19.96 & 20.27 & 17.67 & 18.70 & 19.88 \\
\hline$T\left({ }^{\circ} \mathrm{C}\right)$ & 249 & 383 & & 334 & & 307 & & & 373 & 402 & 236 & 398 & 283 & 349 & 351 & 345 & 350 & 396 & 407 & 386 & \\
\hline
\end{tabular}

Notes: Structural formulas based on 28 oxygens. avg. $=$ average. $T=$ temperature. 


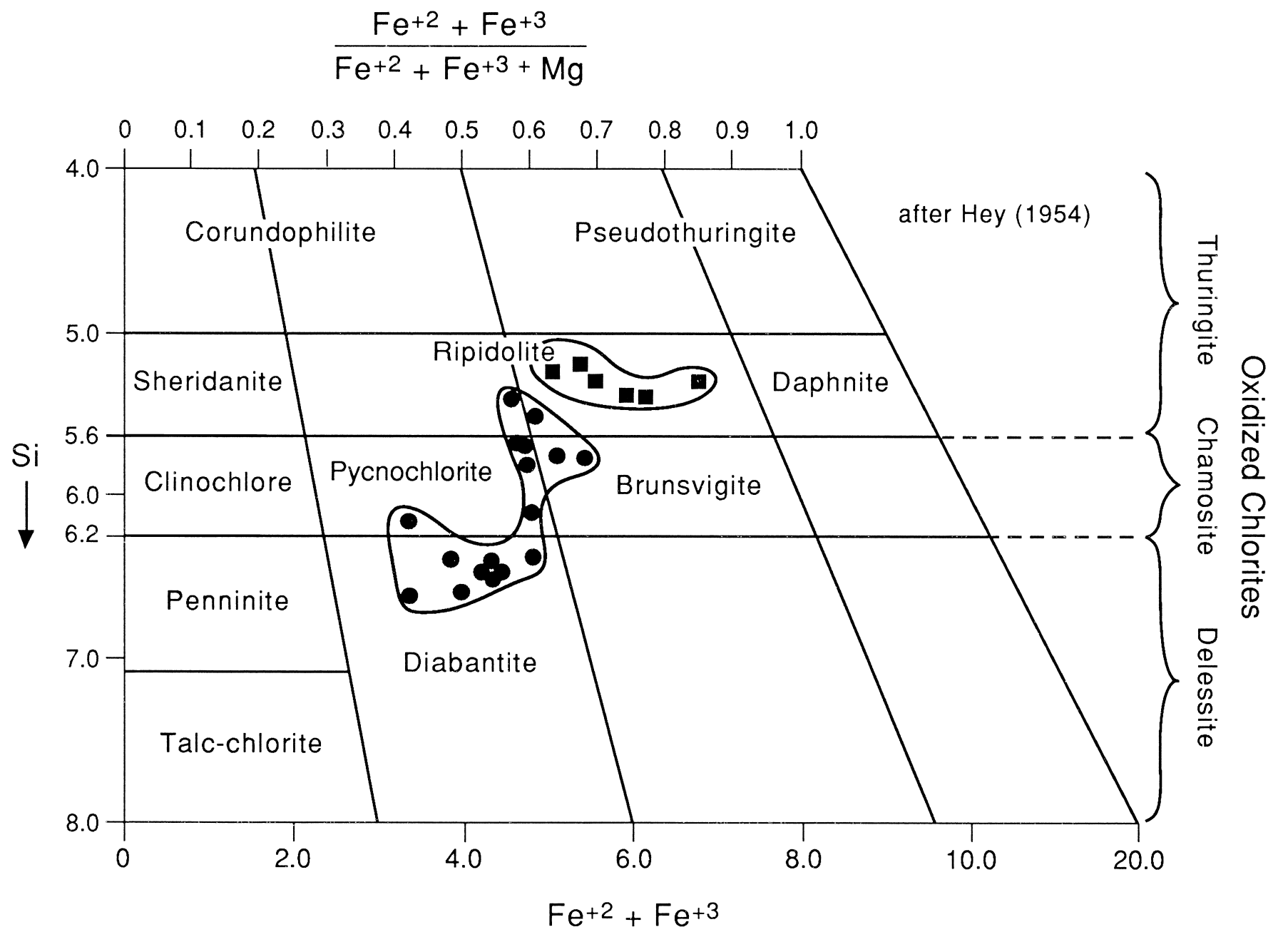

Figure 10. Plot of total iron/total iron + magnesium vs. total iron vs. Si (Hey, 1954) for analyzed chlorite grains from Hole 917A samples. The amount of Fe ${ }^{+3}$ probably would be relatively small in most samples and, when converted to $\mathrm{Fe}^{+2}$ and added (not completed for this figure), would shift the points only a small amount to the right in the diagram.

A probable high temperature gradient and an abundance of hydrothermal fluids played more active roles in the metamorphic processes than lithostatic pressure. We estimate that temperatures were somewhere in the $350^{\circ}-450^{\circ} \mathrm{C}$ range and that pressures were less than 4 $\mathrm{kb}$. If there had been a thick overlying sediment section (e.g., 6-10 $\mathrm{km}$ ), then most was eroded before the eruption of early Paleocene basalt, and possibly before the deposition of the quartz sandstone.

The continental margins around the North Atlantic Ocean were being rifted throughout the Mesozoic. Which of the rifting episodes may be represented by the metasedimentary rocks in Hole 917A is not precisely known. We favor, however, a Late Cretaceous (Campanian-Maastrichtian) time of rifting, when spreading supposedly started in the Labrador Sea.

\section{ACKNOWLEDGMENTS}

We thank Rodey Batiza, Karl Seifert, Hans Christian Larsen, and Andy Saunders for critical reviews. We are especially indebted to personnel in USGS laboratories for the bulk-rock chemical data that were provided. We greatly appreciate the stimulating discussions with science staff during Leg 152. Outstanding ship handling and coring by the ship and drilling crew members of the JOIDES Resolution are gratefully acknowledged.

\section{REFERENCES}

Baedecker, P.A., and McKown, D.M., 1987. Instrumental neutron activation analysis of geochemical samples. In Baedecker, P.A. (Ed.), Analytical Methods Used in the Geologic Division Laboratories of the U.S. Geological Survey for the Inorganic Chemical Analysis of Rock and Mineral Samples. U.S. Geol. Surv. Bull., 1770:H1-H14.

Basaltic Volcanism Study Project (BSVP), 1981. Basaltic Volcanism on the Terrestrial Planets: New York (Pergamon Press).

Battles, D.A., and Barton, M.D., 1995. Arc-related sodic hydrothermal alteration in the western United States. Geology, 23:913-916.

Beach, A., and King, M., 1978. Discussion on pressure solution. J. Geol. Soc. London, 135:649-651.

Bettison, L.A., and Schiffman, P., 1988. Compositional and structural variations of phyllosilicates from the Point Sal ophiolite, California. Am. Mineral., 73:62-76.

Bischoff, J.L., and Rosenbauer, R.J., 1989. Salinity variation in submarine hydrothermal systems by layered double-diffusive convection. J. Geol., 97:613-623.

Cathelineau, M., 1988. Cation site occupancy in chlorites and illites as a function of temperature. Clay Mineral., 23:471-485.

Cathelineau, M., and Nieva, D., 1985. A chlorite solid solution geothermometer: the Loz Azufres (Mexico) geothermal system. Contrib. Mineral. Petrol., 91:235-244.

Chalmers, J.A., and Laursen, K.H., 1995. Labrador Sea: the extent of continental and oceanic crust and the timing of the onset of sea-floor spreading. Mar. Pet. Geol,. 12:205-217. 
Cook, H.E., Johnson, P.D., Matti, J.C., and Zemmels, I., 1975. Methods of sample preparation and X-ray diffraction data analysis, X-ray Mineralogy Laboratory, Deep Sea Drilling Project, University of California, Riverside. In Hayes, D.E., Frakes, L.A., et al., Init. Repts. DSDP, 28: Washington (U.S. Govt. Printing Office), 999-1007.

Dean, W.E., and Arthur, M.A., 1989. Iron-sulfur relationships in organic-carbon-rich sequences, I. Cretaceous western interior seaway. Am. J. Sci., 289:708-743.

de Caritat, P., Hutcheon, I., and Walshe, J.L., 1993. Chlorite geothermometry: a review. Clays Clay Miner., 41:219-239.

Dimberline, A.J., 1986. Electron microscope and microprobe analysis of chlorite-mica stacks in the Wenlock turbidites, mid Wales, U.K. Geol. Mag. 123:299-306.

Engleman, E.E., Jackson, L.L., and Norton, D.R., 1985. Determination of carbonate carbon in geological materials by coulometric titration. Chem. Geol., 53:125-128.

Hellman, P.L., and Henderson, P., 1977. Are rare earth elements mobile during spilitization? Nature, 267:38-40.

Hey, M.H., 1954. A new review of the chlorites. Mineral. Mag., 30:227-292.

Holloway, J.R., 1984. Graphite- $\mathrm{CH}_{4}-\mathrm{H}_{2} \mathrm{O}-\mathrm{CO}_{2}$-equilibria at low grade metamorphic conditions. Geology, 12:455-458.

Huffman, E.W.D., Jr., 1977. Performance of a new automatic carbon dioxide coulometer. Microchem. J., 22:567-573.

Jackson, L.L., Brown, F.W., and Neil, S.T., 1987. Major and minor elements requiring individual determination, classical whole rock analysis, and rapid rock analysis. In Baedecker, P.A. (Ed.), Analytical Methods Used in the Geologic Division Laboratories of the U.S. Geological Survey for the Inorganic Chemical Analysis of Rock and Mineral Samples. U.S. Geol. Surv. Bull., 1770:G1-G23.

Johnson, R.G., and King, B.-S.L., 1987. Energy dispersive X-ray fluorescence spectrometry. In Baedecker, P.A. (Ed.), Analytical Methods Used in the Geologic Division Laboratories of the U.S. Geological Survey for the Inorganic Chemical Analysis of Rock and Mineral Samples. U.S. Geol. Surv. Bull., 1770:F1-F5.

Larsen, H.C., 1980. Geological perspectives of the East Greenland continental margin. Bull. Geol. Soc. Den., 29:77-101.

Larsen, H.C., Saunders, A.D., Clift, P.D., et al., 1994. Proc. ODP, Init. Repts., 152: College Station, TX (Ocean Drilling Program).

Lichte, F.E., Golightly, D.W., and Lamothe, P.J., 1987. Inductively coupled plasma-atomic emission spectrometry. In Baedecker, P.A. (Ed.), Analytical Methods Used in the Geologic Division Laboratories of the U.S. Geological Survey for the Inorganic Chemical Analysis of Rock and Mineral Samples. U.S. Geol. Surv. Bull., 1770: B1-B10.

Masuda, A., Nakamura, N., and Tanaka, T., 1973. Fine structures of mutually normalized rare-earth patterns of chondrites. Geochim. Cosmochim. Acta, 37:239-248.
Nielsen, T.F.D., Soper, N.J., Brooks, C.K., Faller, A.M., Higgins, A.C., and Matthews, D.W., 1981. The pre-basaltic sediments and the lower basalts at Kangerdlugssuaq, East Greenland: their stratigraphy, lithology, paleomagnetism and petrology. Medd. Groenl., Geosci., 6:1-25.

Pearce, J.A., and Cann, J.R., 1973. Tectonic setting of basic volcanic rocks determined using trace element analyses. Earth Planet. Sci. Lett., 19:290-300.

Schiffman, P., and Fridleifsson, G.O., 1991. The smectite-chlorite transition in drillhole $\mathrm{Nj}-15$, Nesjavellir geothermal field, Iceland: XRD, BSE and electron microprobe investigation. J. Metamorph. Geol., 9:679-696.

Shipboard Scientific Party, 1994. Site 917. In Larsen, H.C., Saunders, A.D., Clift, P.D., et al., Proc. ODP, Init. Repts., 152: College Station, TX (Ocean Drilling Program), 107-158.

Soper, N.J., Higgins, A.G., Downie, C., Matthews, D.W., and Brown, P.E., 1976. Late Cretaceous-early Tertiary stratigraphy of the Kangerdlugssuaq area, east Greenland, and the age of opening of the north-east Atlantic. J. Geol. Soc. London, 132:85-104.

Srivastava, S.P., and Verhoef, J., 1992. Evolution of Mesozoic sedimentary basins around the North Central Atlantic: a preliminary plate kinematic solution. In Parnell, J. (Ed.), Basins of the Atlantic Seaboard: Petroleum Geology, Sedimentology and Basin Evolution. Geol. Soc. Spec. Publ. London, 62:397-420.

Taggart, J.E., Jr., Lindsay, J.R., Scott, B.A., Vivit, D.V., Bartel, A.J., and Stewart, K.C., 1987. Analysis of geologic materials by wavelength-dispersive X-ray fluorescence spectrometry. In Baedecker, P.A. (Ed.), Analytical Methods Used in the Geologic Division Laboratories of the U.S. Geological Survey for the Inorganic Chemical Analysis of Rock and Mineral Samples. U.S. Geol. Surv. Bull., 1770:E1-E19.

Turner, F.J., 1981. Metamorphic petrology: mineralogical, field, and tectonic aspects: New York (Hemisphere Publ.).

Winkler, H.G.F., 1976. Petrogenesis of Metamorphic Rocks: New York (Springer-Verlag).

Wood, D.A., 1980. The application of a Th-Hf-Ta diagram to problems of tectonomagmatic classification and to establishing the nature of crustal contamination of basaltic lavas of the British Tertiary volcanic province. Earth Planet. Sci. Lett., 50:11-30.

Date of initial receipt: 1 November 1995

Date of acceptance: 11 June 1996

Ms 152SR-206 

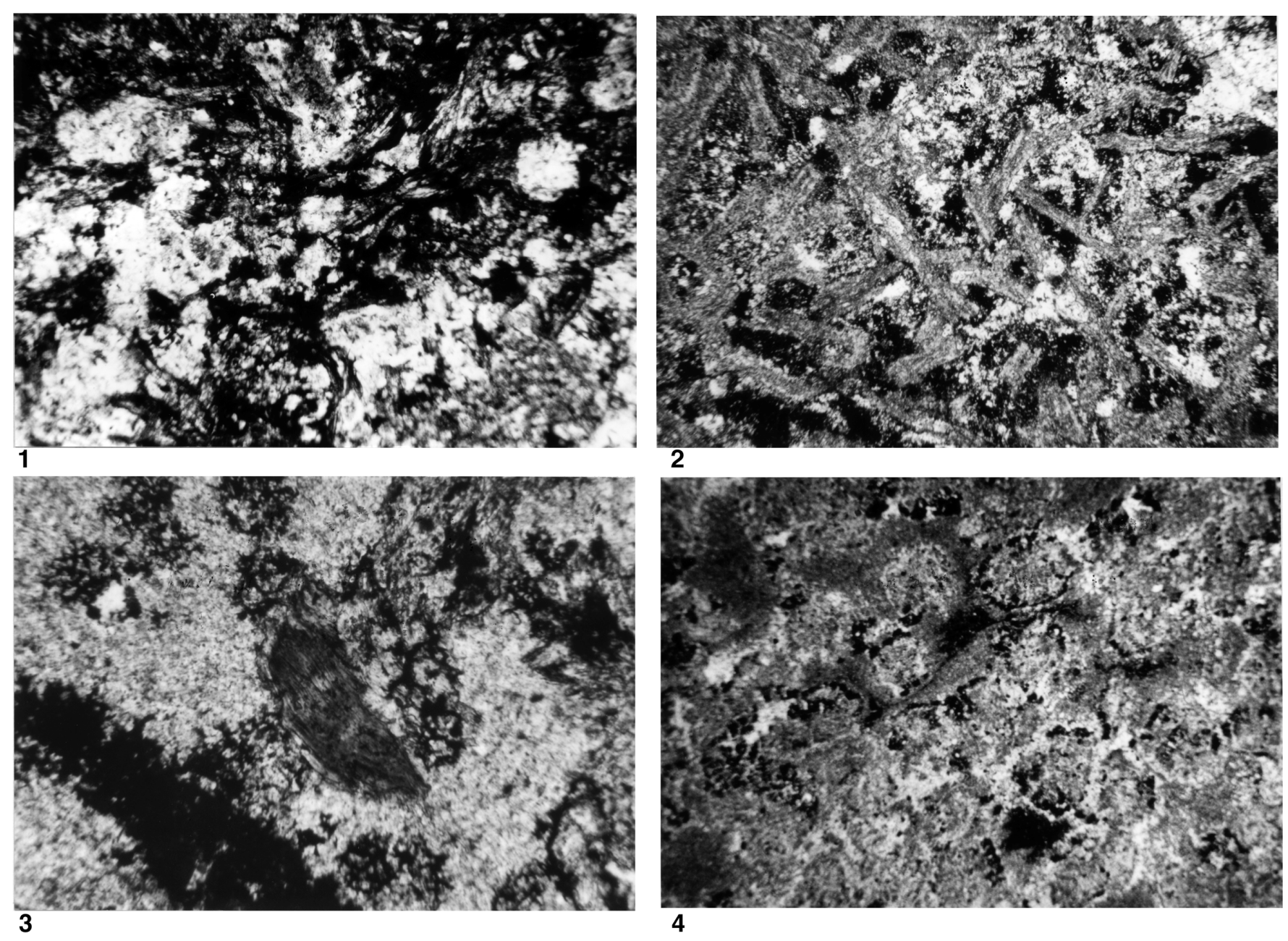

Plate 1. Photomicrographs of thin sections from metasedimentary rocks in Hole 917A. 1. Sample 152-917A-104R-3, 97-98 cm. Chlorite, albite, and graphite have replaced minerals and rock fragments in a probable volcanic sandstone (tuff?). Field of view is $1.05 \mathrm{~mm}$; plane-polarized light. 2. Sample 152-917A-108R1,78-81 cm. Feldspar crystals replaced by chlorite and albite in a possible crystal tuff. Black matrix is graphite rich. Field of view is $4.2 \mathrm{~mm}$; crossed polarized light. 3. Sample 152-917A-103R-1, 104-108 cm. Wispy biotite crystal in graphite (black), chlorite (dark gray), and light-gray matrix (albite and quartz). Field of view is $0.71 \mathrm{~mm}$; plane-polarized light. 4. Sample 152-917A-109R-1, 47-50 cm. Possible replaced foraminifers. Albite outlines spherical to ovoid grains that may be biota. Field of view is $4.2 \mathrm{~mm}$; plane-polarized light. 